\title{
WestVirginiaUniversity
}

THE RESEARCH REPOSITORY @ WVU

Graduate Theses, Dissertations, and Problem Reports

2011

\section{Bias blindness: How police see and don't see hate crimes}

\author{
R. Jake Stump \\ West Virginia University
}

Follow this and additional works at: https://researchrepository.wvu.edu/etd

\section{Recommended Citation}

Stump, R. Jake, "Bias blindness: How police see and don't see hate crimes" (2011). Graduate Theses, Dissertations, and Problem Reports. 809.

https://researchrepository.wvu.edu/etd/809

This Thesis is protected by copyright and/or related rights. It has been brought to you by the The Research Repository @ WVU with permission from the rights-holder(s). You are free to use this Thesis in any way that is permitted by the copyright and related rights legislation that applies to your use. For other uses you must obtain permission from the rights-holder(s) directly, unless additional rights are indicated by a Creative Commons license in the record and/ or on the work itself. This Thesis has been accepted for inclusion in WVU Graduate Theses, Dissertations, and Problem Reports collection by an authorized administrator of The Research Repository @ WVU. For more information, please contact researchrepository@mail.wvu.edu. 


\author{
R. Jake Stump \\ Thesis submitted to the \\ Eberly College of Arts and Sciences \\ at West Virginia University \\ in partial fulfillment of requirements \\ for the degree of \\ Master of Arts \\ in \\ Sociology \\ Corey Colyer, Ph.D., Chair \\ James Nolan, Ph.D. \\ Lawrence Nichols, Ph.D. \\ Stacia Gilliard-Matthews, Ph.D.
}

Division of Sociology and Anthropology

\begin{abstract}
Morgantown, West Virginia
\end{abstract}
2011

Keywords: Hate crime, policing, organizational behavior, classification of social problems

Copyright 2011 R. Jake Stump 


\section{ABSTRACT \\ Bias Blindness: How Police See and Don't See Hate Crimes}

\section{R. Jake Stump}

This study examines how police see and don't see hate crimes. Prior research has drawn mainly on the ambiguity of hate crime laws and definitions, as well as the struggles endured by law enforcement when investigating these cases. This thesis delves deeper into the issue by analyzing the forces that shape officers' perception of hate crimes and how they influence the way they identify, investigate and report bias-motivated incidents. This research focuses on a police force of a small municipality, of less than 75,000 people, located in a Mid-Atlantic state. An analysis of the department's police records and a focus group interview largely drive the findings of this research. Concepts including organizational norms, landmark narratives and classification of social problems are explored as factors that influence police handling of hate crimes. Findings illustrate that distinct properties must exist before police are likely to consider classifying a case a hate crime. 


\section{ACKNOWLEDGEMENTS}

I want to thank my committee for their valuable insight and guidance throughout this journey. They were able to see what I did not see in producing a respectable thesis. I am especially grateful for Dr. James Nolan, who allowed me to work with him on a project measuring the validity of hate crime reporting. That study paved the way for the research presented here. In addition to my committee, I am indebted to the faculty, staff and my fellow graduate students in the Division of Sociology for helping me along the way. Lastly, I couldn't have done this without those who are the driving forces in my life. 


\section{Table of Contents}

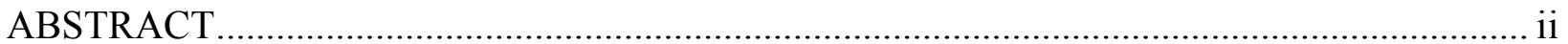

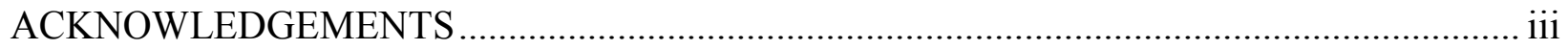

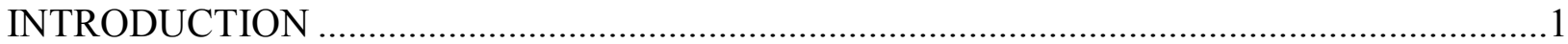

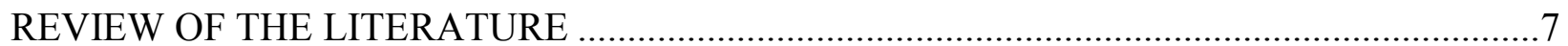

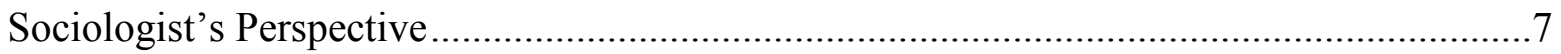

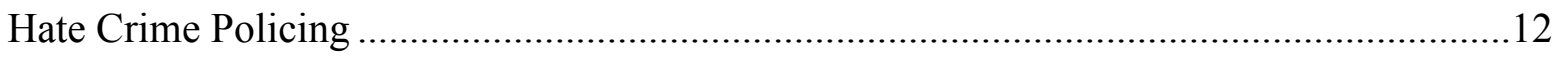

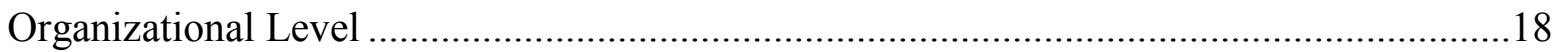

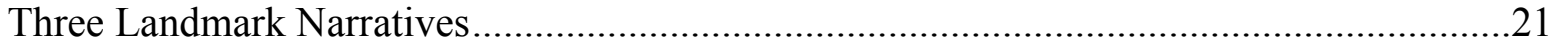

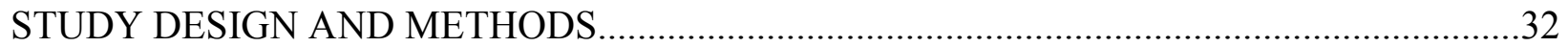

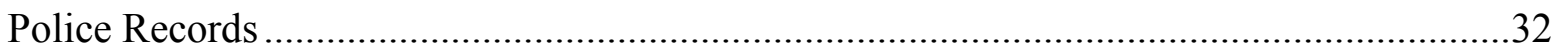

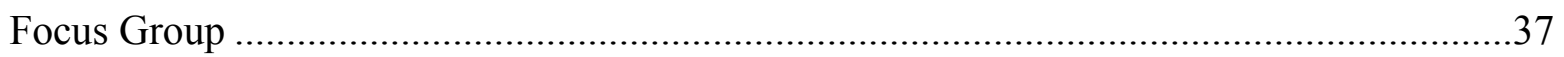

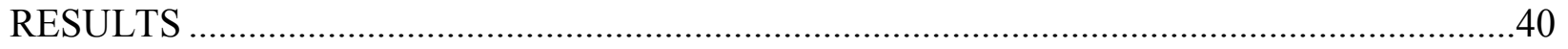

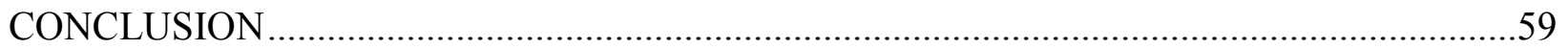

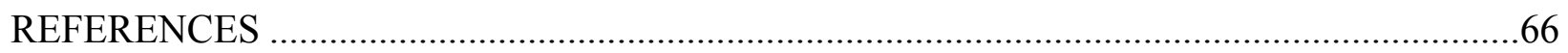




\section{INTRODUCTION}

A black woman walking home from a sub shop on a hot July afternoon encountered a white man walking his two dogs. One dog, without a leash, got uncomfortably close to the woman. She immediately asked the man if he could keep the dog away from her. That request did not garner a response. The woman asked him again to keep the dog away. This time, the man snapped back, "What are you going to do, nigger?" She countered, "I'll kick your dog." The white man then approached the black woman and forcefully bumped into her before running off with his dogs.

Is this a hate crime?

The officer called to the scene of this incident did not think so, since he or she left the 'bias-motivated' checkbox blank on the police report. When filling out incident reports, police have the option to classify an event as bias-motivated ${ }^{1}$ by checking the appropriate box. At a focus group interview, patrol officers with the Mountainville ${ }^{2}$ Police Department agreed with their colleague's decision. They interpreted the offender's actions as an angry, irritated response toward the woman -- not racial bias. One officer theorized:

"It was kind of a burst of anger out of the moment rather than (him) sitting around thinking, 'What am I going to do to them? I'm going to go out and call somebody that name (nigger).",

Therefore, this case did not enter the national hate crimes database as one of 7,783 biasmotivated incidents in 2008 (U.S. Department of Justice 2009). But a team of auditors reviewing the same report disagreed, saying it should have counted as a hate crime (Nolan et al. 2011). The researchers, trained to identify hate crimes, applied both the statistical and legal definitions of

\footnotetext{
${ }^{1}$ 'Hate crime' and 'bias crime' are used interchangeably throughout this paper.

${ }^{2}$ Police agency renamed to protect its identity.
} 
hate crime to the situation and identified bias indicators (explained in detail in Chapter 3) in the exchange. The Federal Bureau of Investigation defines a hate crime as a "criminal offense committed against a person or property which is motivated, in whole or in part, by the offender's bias against race, religion, disability, ethnic/national origin group, or sexual orientation group (FBI 1997, p. 4)." This definition serves merely as a statistical reporting measure. Even if an incident lacks an arrest or is deemed insignificant by an officer, the federal Hate Crime Statistics Act of 1990 still encourages law enforcement to classify and report events that appear biasmotivated.

In the instance above, a racial slur accompanied a physical assault involving a victim and suspect of different races, made it appear to be at least motivated 'in part' by bias. As one officer stated, it's flimsy to argue that the suspect was wholly motivated by bias, that he chose to walk his dogs that day with the full intention of calling a black person a derogatory racial term and deliberately bumping into them. It's safer to assume that his actions were motivated 'in part,' based on the auditors' finding.

Despite their designation of this case as a potential hate crime, it does not invoke the same passionate response as a highly-publicized hate crime that can be described as an unambiguous atrocity. For instance, the 1998 slaying of James Byrd in Jasper, Texas, is regarded by scholars as a national tragedy that pushed the topic of hate crime to the public forefront (Levin 1999; Bennett, Nolan, and Conti 2009; Turpin-Petrosino 2009). In the next chapter, I will present the Byrd murder and two other cases as 'landmark narratives (Nichols 1997)' of hate crime. Byrd, a 49-year-old disabled black man, was walking home from a friend's anniversary party when three white men in a pickup truck stopped to offer him a ride. Byrd never made it home. The men, previously affiliated with white supremacist prison gangs, stopped at a 
convenience store, took him behind the building and pummeled him into unconsciousness. The trio then chained his body to the back of the truck and proceeded to drag him through a rough and winding road for three miles. The force from the dragging decapitated him and severed several of his body parts (Temple-Raston 2002). One of Byrd's attackers that night said he wanted to 'start the Turner Diaries' early, a reference to a race war novel that's considered a 'Bible' for white supremacists. The book depicts the extermination of all Jews and non-whites and also served as a blueprint for the 1995 Oklahoma City bombing (CNN 1997).

Without hesitation, the same officers in my focus group who staunchly asserted that the bumping incident was not a hate crime declared the Byrd murder an irrefutable, clear-cut hate crime. Granted, the severity of the two cases differs greatly: 1) a white man calls a black woman the ' $\mathrm{n}$ word' and intentionally bumps into her after being asked to control his dogs, and 2) three white men with ties to white supremacist groups brutalize, maim and kill a lone black man in a rare, vicious manner.

The first case reflects a low-level offense. It did not generate news headlines or community uproar, and the degree of harm inflicted on the victim paled in comparison to what Byrd endured. The Byrd murder, meanwhile, is considered a grave crime that shook a local community, sparked a wave of intense national news coverage, and paved the way for hate crime legislation. This case serves as a perfect example of an unambiguous atrocity hate crime. Yet at the same time, both examples contain a similar ingredient - racial bias - and fit the statistical definition of hate crime.

This thesis will expand on the complications of classification by exploring how police officers see and don't see hate crimes. In the body bumping example, police failed to see the encounter as a hate crime, although if the circumstances were more serious - say, if the offender 
fatally stabbed the victim, sported swastika tattoos and burned a cross on her lawn - they would likely see it as a hate crime. This sort of reasoning is influenced largely by organizational norms and practices, which serves as a prominent theme throughout this paper.

An organization such as the FBI, Anti-Defamation League, Southern Poverty Law Center, or even a local police force with extensive training in hate crime policing, view such crimes more openly. They advocate for stringent laws and public awareness projects. Police departments fitting into this category may classify low-level offenses as hate crimes as long as the slightest hint of bias exists. They might count a racially-charged 'body bump' as a hate crime. On the other hand, some police departments may not report any hate crimes unless they are unambiguous atrocities - unspeakable acts of extreme violence or behavior, much like the James Byrd case. Otherwise, examples like the body bumping incident are usually dismissed by police as menial offenses spurred by common disputes or other triggering factors (Nolan et al. 2004). Reasons to not report hate crimes from both an individual and organizational perspective include the ambiguity of laws and definitions, inadequate training, and negative or indifferent views on hate crime policing as "not real police work (Bell 2002)."

Police departments are no different than other professions and organizations that establish measurement and/or classification criteria to gauge perceived social problems. Organizational practices play a significant role in how things are defined, measured and classified. For instance, medical examiners classify the causes of death in a variety of ways - namely homicide, suicide, accident and natural causes (Timmermans 2006). As a social event, a person's final breath does not make death official. An individual's death maneuvers through several bureaucratic processes before the death is deemed final and official. As I will explain later in the literature review section (Chapter 2), rulings and classifications from professional authorities result in 
administrative consequences. These 'official' judgments are determined through bureaucratic systems and are accepted by various audiences. Classifications prevail as truth to the general public. If Mountainville Police were to classify five hate crimes per day, actors within the community (i.e. news media, residents, elected officials) would perceive that a hate crime problem exists. The act of classification wields power, even when the final judgment is not correct in reality. Ambiguities often appear in a professional's work to complicate the classification process. For example, a mangled automobile is discovered at the bottom of a cliff with its driver dead inside. This could be classified as a homicide, suicide, or accident.

Organizationally-constructed guidelines can hinder the vision of official scorekeepers or cause them to veer from the script. With many professions, the scorekeepers charged with making classifications have a set of formal and informal codes at their disposal. These codes clash with one another and further compound the classification process. From the world of hate crime policing, the formal code would consist of employing both the legal and statistical definitions to a possible bias-related occurrence, as well as detecting bias indicators. If the scenario fits the criteria, the officer should then duly record it as bias-motivated, regardless of any arrests or the outcome of the case. Formal codes are written policies and procedures that officers are expected to abide by. However, informal codes represent unwritten but routine ways of handling situations on the job. These codes, too, emerge within an organizational context and tend to override formal codes. Garfinkel (1967) showcased this phenomenon by explaining how jurors make decisions. As I will also discuss in the literature review section, police officers develop routines and practices - which are not outlined in the official hate crime definitions and criminal statutes - that allow them to separate non-bias crimes from the bias ones (Bell 2002). 
For this paper, I will draw on data gathered from an assessment of one local police department's hate crime reporting practices. The data includes a random sample of that agency's official police records for the year 2008 and a focus group interview of four patrol officers and a lieutenant regarding hate crime policing. I will also analyze police narratives for cases that were classified as bias-motivated by either the reporting officer or the outside research team conducting the original assessment (Nolan et al. 2011). The narratives are written accounts of the incident from the eyes of the responding officer.

The agency of study - Mountainville Police Department -- is located in a Mid-Atlantic state and serves as that state's largest municipal police department. It also represents the most diverse community in this state. Despite this limited focus, my findings can assist not only law enforcement in identifying, reporting and classifying hate crime, but organizations in measuring and classifying certain social problems. I will illustrate how police officers handle biasmotivated situations and showcase the struggles they encounter even two decades following passage of the federal Hate Crime Statistics Act. I will conclude that incidents and offenses that meet the statistical and/or criminal criteria for hate crime are commonly seen by police as two types: An ambiguous, low-level occurrence that contains ordinary properties and an unambiguous atrocity that contains extraordinary properties.

Police are more inclined to count only unambiguous atrocities as hate crimes, yet this is not stated in any official coding rules. In reality, most hate crimes are not unambiguous atrocities. Instead, they consist mostly of the ambiguous, low-level, ordinary occurrences. In the organization studied in this report, the scorekeepers are more apt to use informal rules and count only extreme, unambiguous examples as hate crimes. As I will present in my findings, certain qualities must exist for police to see hate crimes. 


\section{REVIEW OF THE LITERATURE}

The literature reviewed for this paper extends beyond just hate crime research. It explores other sociological ideas that affect the identification, reporting and, particularly, the classification of perceived social problems. While this paper relies partly on research outside of the hate crimes field, it refers back to the topic of how law enforcement sees a particular social phenomenon. The challenges of seeing hate crime do not begin and end with an individual patrol officer responding to a call. Explaining issues related to classification and measurement from various perspectives (outside of law enforcement) helps us understand the forces that influence decisions on a local level (within law enforcement). Literature outlined in this chapter provides a framework for explaining the various forces that complicate classification and scorekeeping. This chapter is divided into sections that discuss classification problems from three different platforms: 1) the sociologist's perspective, 2) the hate crime policing view, and 3) the organizational level.

Lastly in this chapter, I will examine the concept of landmark narratives and how three specific cases surfaced as hate crime atrocity archetypes. During my focus group interview, officers discussed two of the three landmark narratives by their own initiation. I will demonstrate how these narratives shape an officer's view of hate crime.

\section{The Sociologist's Perspective}

Prior sociological research asserts that classifying and measuring social problems pose a tricky task. Some sociologists place blame on the use of official statistics for influencing how social problems are recorded (Kitsuse and Cicourel 1963; Merton 1957; Zerubavel 1996; Best 2001). Focusing on deviant behavior, Kitsuse and Cicourel argued that explaining the rates of deviance among segments of the population were problematic, largely due to official statistics' 
lack of 'appropriateness' and 'reliability.' The authors heavily referenced the work of noted sociologist Robert K. Merton, who laid groundwork for discrediting so-called 'official' statistics in the 1950s. In their paper, Kitsuse and Cicourel state that official statistics use categories unsuitable for the classification of deviant behavior. These statistics, at best, classify the same forms of deviant behavior in different categories and different forms in the same categories, they said. In sum, the "sources or contexts" of deviant behavior are obscured, yet they still contribute to the official recording.

Similarly, the sources and contexts of hate crimes that comprise the official statistics remain unknown. When police report hate crimes, they eventually enter the national hate crimes database, which was developed by the FBI as an adjunct to the existing Uniform Crime Reporting (UCR) program. From this database, the FBI produces an annual Hate Crime Statistics publication. Since 1992, these publications have offered a wealth of information regarding the 'official' records of hate crimes (e.g. the number of hate crimes reported by jurisdiction, the number of participating agencies, incidents by bias type). While the publication is frequently cited by law enforcement officials and hate crime scholars, it does not gauge the statistical accuracy of the actual reports. The "sources or contexts," as discussed by Kitsuse and Cicourel, are obscured in these official statistics, as well. Furthermore, Merton (1957) deemed official statistics 'unreliable' due to the layers of error intervening between an actual event and the recorded event. Merton established this argument after studying deviant behavior. He claimed that individuals manifesting deviant behavior were apprehended, classified and recorded as deviants in society, while others were not. Kitsuse and Cicourel expand on this concept by stating: 
It is assumed that if the acts of all such individuals were called to the attention of the official agencies they would be defined as deviant and so classified and recorded. (P.

This can apply to law enforcement's reporting of hate crime. It is unfathomable to think that every bias-motivated incident or offense that takes place will be classified and recorded by authorities. In some cases, police do respond to bias situations but do not record them as such. Consider this fictitious example: A group of men attack a man exiting a gay bar. They call him 'fag' and 'queer' as they punch and kick him. An officer responds to the scene but does not duly record it as a hate crime. Because police failed to record it as a hate crime, it would not be counted as an 'official' hate crime. Yet that official ruling would not mean the incident ceased to exist as a hate crime in reality. Therefore, events recorded by police may not mirror what had taken place in reality. Police seldom witness a crime firsthand and must rely on evidence and conflicting statements from victims, witnesses and offenders to make a determination. That determination may not match up to what had actually occurred.

Kitsuse and Cicourel also tackle the problem by examining the production of definitions. Organizations typically define social problems, and the definition then allows them to serve as scorekeepers of said problem. The authors acknowledge that the definition of deviant behavior in their study was organizationally processed. Because of that, it presents a reliability issue with the 'official' statistics:

First, the focus on the processes by which rates are produced allows us to consider any set of statistics to be relevant. The question to be asked is not about the 'appropriateness' of the statistics, but about the definitions incorporated in the 
categories applied by the personnel of the rate-producing social system to identify, classify and record behavior as deviant. (P. 132)

In reference to the rates of delinquency reported by a police department, the authors ask what criteria officers use to identify and process youths as delinquent. They find that the criteria are too vague and entail a wide range of behaviors. Criteria for hate crime classification are also vague - evident by the array of definitions at law enforcement's disposal (an issue I will delve into later in this chapter).

The "island of meaning" concept represents another perspective on classification from a sociologist. Zerubavel (1996) described an island of meaning as a cluster of things (acts, events, objects, traits) that are regarded as more similar to one another than to anything outside the cluster. For example, potters and filmmakers become 'artists,' and homosexuality and necrophilia become 'perversions.' Using this framework, when we think of burglary and rape, we think of those as 'crimes.' Zerubavel explains that people carve social clusters in their minds by regarding all cluster members as similar or alike. This fits into how police see crimes. With the findings I will present later, I believe that hate crimes fail to enter that cluster of 'crime.' Hate crimes have not reached the same status as more concrete crimes such as kidnapping, assault or destruction of property. All of these types of traditional, standard crimes fit perfectly into the cluster, but hate crimes are still perceived as new and ambiguous despite the push for awareness over the last two decades.

The term 'hate crime' did not enter the nation's vocabulary until the 1980s, when a noticeable increase in organized racist groups (e.g. skinheads) and bias-related attacks occurred (FBI 2010). But what we now know as hate crimes have existed throughout the world's history (e.g. racial violence in the southern U.S., Roman persecution of Christians, the Nazis' "Final 
Solution" for the Jews). The official classification of hate crimes would not have occurred until the concept was defined and introduced as a term to society. The emergence of a perceived hate crime epidemic in recent history was made possible by claims-making and institutionalization (Best 1999). Best developed a process outlining the indirect dialogue between the various types of claims-makers who shape the construction of social problems: (1) primary claims-makers, which typically consist of victims, activists and spokespersons that make assertions about perceived problems in the public arena; and (2) secondary claims-makers, members of news organizations and makers of popular culture who rework, repeat, translate and transform claims.

In a look at new crimes and victims that surfaced in the 1980s and 1990s, Best examined road rage, random violence, gangs, stalking and hate crimes, among other issues played out in the national media during the time period. Hate crimes, along with stalking, according to Best, endured as a new crime problem differently than road rage and 'wilding,' an abstract term that was linked to the Central Park jogger case and described how youths looked to cause a ruckus and raise hell for no apparent reason. Those problems - freeway violence and wilding - seemed to fade away from the limelight after much media dissection. Stalking and hate crimes, on the other hand, became institutionalized. These two crimes survived through legislation, the criminal justice system and various programs aimed to deal with those problems. California passed the first antistalking law in 1990. By 1993, 48 states and Washington, D.C. adopted similar laws. Claims-makers, in the form of the media, stalking victims and advocates for antistalking laws, helped shape the institutionalization of such policies. "Star-stalking" had become a prominent issue in the 1980s and was given considerable media attention. Stalking was also reframed as a women's issue and considered a precursor to serious violence by a man against a woman. 
Although Best classified hate crime as another institutionalized new crime, it did not gain the same type of traction as the stalking issue. An officer may be more inclined to see a stalking case than a hate crime case. Stalking cases are typically clearer - a man follows his ex-girlfriend to work every day; a fan of a celebrity writes him or her threatening letters. Authorities can quickly determine if someone is being stalked. With hate crimes, unless the evidence is obvious (e.g. lynchings, painted swastikas), police struggle to identify if it was committed because of bias.

With the advent of advocacy groups for social problems such as stalking, the claims and scorekeeping of these groups and government organizations can vary. Take the missing children "epidemic" of the 1980s, observed by Best (1990). Some advocacy groups claimed 50,000 children went missing each year, while the FBI, the official scorekeeper, believed that number was only a few hundred. This discrepancy spurs the question of how to develop a sociological understanding of contradictory claims and figures that appear in the public space. A multitude of factors, from moral panics to group interests, produce these conflicts. This discussion calls for the further development of a theoretical model that captures the interchange of claims-making voices in the definition of various social problems, like hate crime (Nichols, Nolan \& Colyer 2008).

\section{Hate Crime Policing}

Existing literature on hate crime recognizes that classifying a criminal act as biasmotivated is not a clear-cut procedure (Bell 2002; Nolan et al. 2004). Police quickly identify crimes like burglary, kidnapping and murder. Usually in those cases, identifying motives and gathering evidence are simpler for police compared to hate crime investigations. In the example 
provided at the beginning of this paper, police can, at the very least, see that the white man walking his dogs committed a low-level assault by body bumping the black woman. Proving that it took place due to his feelings toward African-Americans is harder to establish.

The way police see or don't see hate crimes ultimately affects the statistics of hate crime reporting. The case of the body bump represents one example of a hate crime undercount (or false negative) that researchers, including myself, found in an audit of the Mountainville Police Department's records (Nolan et al. 2011). That study's researchers set out to identify any hate crime underreporting and overreporting by the department. Hate crime classification error occurs when law enforcement either underreport or overreport hate crimes. Underreporting occurs when officers fail to record an incident as bias-motivated even though it fits the criteria. Overreporting, on the other hand, occurs when police classify an offense as a hate crime when, in actuality, it is not. We concluded that Mountainville PD underreported hate crimes more than it overreported them.

It is also crucial to recognize the dissimilarities of hate crime policing and reporting between jurisdictions in the U.S. For example, California led the nation in hate crimes $(1,381)$ reported to the FBI's Uniform Crime Reporting (UCR) Program in 2008. On the other end of the spectrum, Mississippi reported four. This does not mean, necessarily, that hate crimes are more likely to occur in California than Mississippi. A multitude of factors - e.g. population size, the number of participating agencies, the dedication of accurate hate crime reporting on the local level - influence these figures.

In $2008,13,690$ law enforcement agencies in the country submitted hate crime data to the UCR Program (U.S. Department of Justice 2009). Of those agencies, 2,145 reported hate crime incidents and offenses. Does that mean hate crimes never occurred in the jurisdictions of the 
other 10,000-plus agencies? No. To participate in the FBI program, an agency must simply complete a hate crime incident report or submit a form signed by the police chief that states no hate crimes had occurred that year. Though participation in the program is voluntary, most states require law enforcement agencies to submit data.

One of the reasons why police cannot see hate crimes is due to the confusion and ambiguity that emerges from the wide range of laws and definitions present on both the federal and local levels. West Virginia, for instance, has its own hate crime definition, which varies from the FBI's version and further complicates the issue: "All persons within the boundaries of the state of West Virginia have the right to be free from any violence, or intimidation by threat of violence, committed against their persons or property because of their race, color, religion, ancestry, national origin, political affiliation or sex (West Virginia State Code: §61-6-21).” This serves as a legal definition of hate crime because it is part of West Virginia's criminal code. The FBI definition, though referenced heavily in hate crime literature, is not a distinct criminal offense; it is just a definition utilized for statistical reporting. The federal government has the authority to investigate and prosecute hate crimes as "civil rights violations," yet there are no federal "hate crime violations," per se. A focus group interview (Nolan et al. 2011) illustrated the confusion among police officers who appeared unclear as to whether classifying a crime as biasmotivated on a report could result in criminal charges and prosecution.

Note that West Virginia's statute does not include disability and sexual orientation as protected categories, although those groups are included in the FBI definition. Therefore, if a person is a victimized in West Virginia because he or she is gay or disabled, the offender is not subject to criminal prosecution under the state hate crime code. Although crimes committed because of sexual orientation or disability bias are not prosecuted as hate crimes in West 
Virginia, officers and agencies still must classify those accounts as bias crimes for federal statistical purposes. In another difference between the two definitions, West Virginia law protects victims of political affiliation and gender bias, which are not included in the FBI's version.

Forty-five states and Washington, D.C. have their own hate crime statutes (AntiDefamation League 2008), yet there is no uniformity across state boundaries. Hate crime laws also change over time and the protected groups vary from state to state, allowing critics to question the credibility of these laws (Jenness 1999). Wyoming, for example, does not have a hate crime statute although one of the most infamous hate crimes happened there. On Oct. 7, 1998, Matthew Shepard, a gay 21-year-old college student, was offered a ride home from two men he'd met that night at a Laramie, Wyoming bar. According to witness testimonies, the two men - Russell Henderson and Aaron McKinney - had planned to rob a gay man. They found the perfect target when Shepard reportedly revealed to them that he was gay. After offering Shepard a ride, Henderson and McKinney drove him to a remote area where they robbed, pistol-whipped and tortured their victim into a bloody pulp. They tied Shepard to a fence and left him for dead, though he was still alive when a cyclist discovered him 18 hours after the vicious attack. He died four days later. Despite the national attention and push for hate crime laws following the ghastly assault, Wyoming still does not have its own bias crime statute (DeBoskey 2009). Meanwhile, Wyoming's neighbor to the south, Colorado, carries a hate crime law protecting individuals victimized because of race, sexual orientation, disability and political affiliation. If the same Matthew Shepard tragedy had occurred across the border in Colorado, Shepard's attackers would've likely faced hate crime charges. 
In addition to the statistical and legal definitions, laws exist regarding the reporting of hate crimes by police. West Virginia law (§15-2-24) mandates all state, county and municipal law enforcement agencies to report crimes according to UCR definitions. The UCR was briefly discussed earlier in this paper. In the early 1990s, the FBI established the Hate Crime Data Collection Program as an addition to the existing - and well-established - UCR Program. A national crime data collection system, the UCR Program involves more than 17,000 state and local law enforcement agencies that voluntarily report crime statistics to the FBI. Two subprograms exist under the UCR umbrella: Summary UCR and the National Incident-Based Reporting System (NIBRS). Hate crimes are reported in these two formats. Data collected under Summary UCR are quarterly reports that contain little or no information about the victim and offender while NIBRS reports include details about the victim, offender, offense and more.

The Hate Crime Statistics Act was signed into law by President George H.W. Bush in 1990 as a result of an emerging awareness of bias-related attacks. At the recommendation of the U.S. attorney general, a national hate crimes database was established to maintain a consistent record of bias-motivated activity throughout the country (Levin \& McDevitt 2003). The Act does not criminalize or stiffen penalties for bias offenses; it only mandates that the attorney general acquire data on crimes motivated by bias. Advocacy groups and sponsors of the legislation believed it would, 1) raise the public's awareness about the nature and extent of hate crimes, 2) provide a baseline for research and program development, 3) help support the development of effective hate crime legislation, 4) provide law enforcement with information to help them become more effective in working with communities to combat hate crime, and 5) encourage victims to come forward and get the support and assistance they may need (Nolan and Akiyama 1999). The FBI has collected and published hate crime statistics annually since 1992. 
Furthermore, empirical research has identified ambiguity in the very hate crime reporting that helps produce those annual published reports (Jenness \& Grattet 2001; McDevitt, et al. 2000; McDevitt, et al. 2003).

The mere existence of inconsistencies, various laws and plural definitions produces confusion and ambiguity, leading to "a surplus of possible interpretations (Grattet and Jenness 2005)." In order to deal with the ambiguous nature of hate crimes, police develop routines and practices - which are not outlined in the statistical and legal definitions -- that allow them to separate the non-bias crimes from the bias ones, whether those methods are accurate or not. Bell (2002) stated that police often don't want to follow up on cases that they consider trivial; therefore, those situations would likely be marked as non-bias crimes. Bell also provided this list of items that influence an officer's decision to seek charges:

\section{Different identities.}

2. Looking at the crime's context - ruling out other motives

3. Developing the typical non-hate crime

4. Weeding out false reports

5. Bias indicators

6. Policing crime and not speech - there must be action and not just words

7. Relationship - more likely to happen if the victim and offender do not know each other

8. Race and the decision to charge

9. The less ambiguous the better

10. Tended not to prosecute young juveniles. 
Law enforcement cannot necessarily detect a bias crime via a transparent psychological

process. That is, hate crimes cannot be seen by everyone in the same manner as they see the sun. Everyone can agree on the concrete properties of the sun while observing it: It is bright. It is in the sky. It sets in the West and rises in the East. But not everyone can see hate crimes through the same objective lenses. Instead, officers must learn to see hate crimes in a way that farmers and archaeologists see soil (Nolan et al. 2004). To most people, all soil is dirt. But through an expert lens, soil takes on different properties. This approach, dubbed the 'professional vision,' is outlined by Goodwin (1994) who argued that 'all vision is perspectival and lodged within endogenous communities of practice.'

\section{Organizational Level}

As noted earlier, organizations play a key role in how things are measured and classified. Organizations define a problem, establish guidelines and criteria for classification/measurement of the problem, classify or measure the problem, and foster formal and informal codes for dealing with the problem. Altheide (2003) described scorekeeping as an institutionalized practice.

Professions, such as medical examiners, as explained briefly in the introduction, contain routine processes that aid in decision-making or classification. Death investigators are charged with defining the boundaries of homicide, suicide, accident and natural death (Timmermans 2006). The act of investigating death is legitimized as a 'professional authority,' which is accorded to an occupational group to conduct professional work and have its judgments accepted by various audiences. Professional authority is furthered when professionals are able to establish definitions of things. 
Timmermans described death as a social event, not just an individual occurrence. The work of medical examiners makes death official - it is not necessarily official when a person's heart, brain and other vital functions expire permanently. The final act of filing a death certificate, where an examiner notes the time and cause of death, makes death official. These decisions lead to administrative consequences. The same applies to the decisions made by police investigating hate crimes. To help explain this, advocacy groups can make claims about hate crime. However, these are not viewed as official claims. When an officer classifies an incident as a hate crime, that ruling is perceived as the truth. After that determination, news media may pick up on the story. From there, community members and elected officials take notice. These are the consequences that emerge from classification. As mentioned earlier in this chapter, California police reported 1,381 hate crimes in 2008 compared to Mississippi's four. Each police agency's approach to hate crime classification in those two states forces audiences to consider the following: a) California has a hate crime epidemic and Mississippi is a peace haven for diverse groups; or b) police officers in California are more likely to report hate crimes than their counterparts in Mississippi.

Timmermans also demonstrates how different organizations can clash over the classification of certain things. He cites Klinenberg (2002), who documented the 1995 Chicago heat wave. The medical examiner classified deaths as heat-related that summer although the mayor challenged such classifications. The mayor deemed those deaths as 'natural.' Forensic experts and public health officials defended the medical examiner's classification of these deaths, and soon, the mayor stopped questioning the examiner. Fearful of political repercussions, the mayor believed that attributing deaths to the heat wave could damage his career. 
In their paper on deviant behavior, Kitsuse and Cicourel (1963) touched on organizations' roles in measuring the social problem. They outlined how (1) groups and organizations come to define different forms of behavior as deviant, (2) individuals manifesting such behaviors are organizationally processed to produce rates of deviant behavior, and (3) acts officially or unofficially defined as deviant are generated by conditions including family organization, role inconsistencies or situational pressures. From a hate crime perspective, organizations, such as the FBI, came to define criminal acts motivated by bias as hate crimes. State policymakers also defined hate crimes on the local level through the legislative process. In drafting and pushing through legislation, a definition must be made clear to accompany any law that is passed. Secondly, it is these definitions that allow organizations, such as the FBI or police agencies, to process cases matching these definitions in order to produce rates of hate crime. Thirdly, cases defined as hate crimes are generated by a set of organizationally-established conditions.

A report on the routines of jurors (Garfinkel 1967) highlights how individuals engage in decision-making within an organizational context. In the same manner in which police are trained to respond to a crime scene and gather arguments from all parties involved, jurors sit in a courtroom and sort alternative depictions made by lawyers, witnesses and other jurors of what happened and why. Jurors then determine "what is fact and what is fancy; between what actually happened and what 'merely appeared' to happen."

If ambiguities appeared in a case before jurors, they tended to mask or ignore it. Thus, (a) regardless of the procedures that were actually followed, jurors identified them with procedures depicted in the official line; (b) in their ideal accounts of how jurors arrived at their decisions, 
jurors told how the right decision was arrived at; (c) in their idealized accounts, jurors talked as

if they knew the rules of decision making before they went into the deliberations. (P. 113)

Garfinkel showed that the work of jurors is routinized and that they often rely on an informal code of conduct rather than following a more formal, official line. Police officers follow routine organizational procedures, not only when dealing with hate crimes, but with any other investigation or reporting. Jenkins (1994) illustrated that routine organizational procedures among officers can lead to variation in estimates and statistics. In exploring the serial murder phenomenon, Jenkins noted that 17 percent of homicide circumstances were classified as 'unknown' between 1976 and 1985. Congress ended up taking this data and misinterpreting it to claim that these 'unknown' classifications of homicide were the work of serial killers. Jenkins explained the mishap: police usually must file an official report within a brief period of time from the incident (murder). In some cases, officers cannot identify a suspect or other pertinent information within the timeframe, so they go ahead and enter 'unknown' into the appropriate categories. As time elapses, an officer can do one of two things, which are dependent on organizational procedures: (1) they can submit a report with new information to replace the first one, or (2) not submit a revised version of the report because they already filed one, and they have more important things to tend to.

\section{Three Landmark Narratives}

For purposes of this research, I have singled out three hate crime cases that can be typified as landmark narratives. Before delving into those examples, it is important to understand the workings of a landmark narrative, a concept popularized by Nichols (1997). According to Nichols, a landmark narrative acts as a definitive example of an alleged social problem. His 
research examined how the Bank of Boston emerged as a landmark narrative for money laundering and white-collar crime in the mid-1980s. In 1985, prosecutors charged the bank with violating currency transaction reporting requirements under the federal Bank Secrecy $\mathrm{Act}^{3}$. Although much of the banking industry at the time failed to comply with such laws, national news organizations latched onto this particular case and elevated it to the status of a landmark narrative through the "successful use of storytelling."

To further illustrate how the Bank of Boston transformed into a landmark narrative, Nichols identified how claimsmakers distinguished the case from others. The scandal not only appeared in national news headlines, but it eventually cemented its place in criminology textbooks and business journals as a case that established precedence.

In the same way that the Bank of Boston became synonymous with money laundering and white-collar crime, certain bias-related cases persist as landmark narratives of hate crime. Two of the three examples I am about to discuss surfaced as national tragedies. As I have mentioned throughout this paper, it is less challenging for police to classify a hate crime if it is an unambiguous atrocity. The murders of James Byrd and Matthew Shepard fit that mold. My third example can be argued as a landmark narrative on a regional level. I will also devote my space to this third case -- the alleged torture of Megan Williams - due to its regional proximity to the Mountainville Police Department. Social constructions by claimsmakers, particularly news agencies, helped propel these cases to landmark narrative status. It is my assumption that if you were instructed to give an example of a hate crime to someone uninformed about the topic, you would likely mention one of these three cases if you lived in the Mountainville community.

\footnotetext{
${ }^{3}$ The Bank of Boston pleaded guilty to a felony charge of failing to report $\$ 1.2$ billion in cash transfers to foreign banks. The bank paid a criminal fine of $\$ 500,000$ (Nichols 1997).
} 
As discussed previously, James Byrd was beaten and then chained to the back of a pickup truck by three white men previously affiliated with white supremacist prison gangs. The group then dragged his body through culverts and winding patches of road, ultimately killing him. Stories on the vicious slaying appeared in newspapers across the country and on national television newscasts (Turpin-Petrosino 2009). The murder created community uproar and attracted civil rights figures such as Jesse Jackson to the area. A movie about the crime, Jasper, Texas, was produced and aired on Showtime in 2003, while a documentary titled Two Towns of Jasper premiered on PBS that year. Despite the public's identification of the Byrd murder as a true hate crime, the police handling the case could not officially classify it as one. Texas state law, at the time, did not have a hate crime law on the books. Still, the killing quickly emerged as a landmark narrative, paving the way for the passage of a Texas hate crime law. A decade later, its status as a landmark narrative persevered as a federal law was named jointly after Byrd and Matthew Shepard. In October 2009, President Barack Obama signed into law the Matthew Shepard and James Byrd Jr. Hate Crimes Prevention Act ${ }^{4}$. Shepard is another face, symbol and icon of hate crime. Also discussed earlier in this paper, Shepard was the gay college student who was tied to a wooden fencepost, beaten and left to die slowly. Like Byrd's attackers, Shepard's assailants would not face hate crime charges in court, as Wyoming did not have a hate crime law. Without a legal classification as a hate crime, Shepard's case remains a landmark narrative, mostly due to the extensive media coverage of the murder. The crimes committed against Byrd and Shepard were not just local events. They transcended into national tragedies (Levin 1999).

The tale of Megan Williams did not quite reach those levels. Yet I shall argue that her case is a local landmark narrative for hate crime. Williams, a 20-year-old black woman, was

\footnotetext{
${ }^{4}$ This bill expanded federal hate crime laws to include offenses motivated by a victim's actual or perceived gender, sexual orientation, gender identity, or disability.
} 
allegedly kidnapped, raped and tortured by six white people in 2007. Police had received a tip about a female being held against her will at a ramshackle trailer in the unincorporated town of Big Creek, Logan County, nestled in the southern coalfields of West Virginia. Acting on the tip, police arrived at the mobile home and encountered a 49-year-old white woman, Frankie Brewster, the homeowner, sitting on the front porch - door left wide open. The officers asked her if anyone else was at the residence, to which Brewster replied she was alone. Brewster got up from her chair and walked toward the door. A black female (Williams) then limped out onto the porch with her arms reaching out to police. She uttered the words, 'Help me (Harki 2007).'

Brewster acted as if she didn't know what was going on. Upon further investigation, authorities unveiled a tale of weeklong abuse and torture inflicted on Williams. Investigators concluded that Brewster and five other people stabbed Williams, pulled her hair, choked her, doused her with scolding water and hot wax, threatened her with death, and forced her to do the following: perform oral sex, drink from a toilet, lick blood, and eat rat, dog and human feces. This gamut of abuse left Williams with stab wounds, a fractured wrist, multiple bruises and psychological trauma. She required surgery on her stabbed leg and spent several days in a hospital. The six suspects charged included Brewster; her son, Bobby Brewster, 24; Karen Burton, 46; her daughter, Alisha Burton, 23; Danny Combs, 20; and George Messer, 27.

The extreme nature of this crime generated media buzz throughout West Virginia and the nation. It thrust an otherwise humdrum rural locale into the media spotlight. Logan County's racial makeup is predominantly white -96 percent - while nearly one-fourth of the population lives in poverty (U.S. Census Bureau, 2000). Coal, timber and agriculture once represented the area's largest industries, but those resources began fading away in the 1960s. Outside of West Virginia, that region wasn't known for much, except maybe for the Buffalo Creek disaster in 
1972, when a coal slurry dam burst and killed 125 people. More than three decades later, Logan County garnered unwanted negative attention again.

In the earliest news accounts, Williams was portrayed as a sympathetic figure -- a lone racial minority female with a learning disability. She was held captive, beaten and humiliated by a group of rural white savages. Newspapers published images of Williams bandaged and battered in a hospital bed. Other pictures showed her clutching teddy bears or her mother consoling her like a child. She was small in physical stature, standing at around five-feet tall. These factors enabled her to be cast as an ideal, innocent victim in the press. The headline to the Charleston Gazette's first account (Sept. 11, 2007) of the story, plastered on the front page, read, "6 arrested, charged in torture; Authorities believe racism played role in woman's ordeal.” This initial story implied it was racially-motivated. The lead sentence read, “Carmen Williams doesn’t understand why her 20-year-old daughter was tortured, raped and tied up in a shed." It continued, "Police tell her that what happened was probably a hate crime, that it happened because Megan Williams is black,' followed by a quote from Williams' mother, who said, "Every time they stabbed her, they called her "nigger."

The author relied heavily on the victim's parents for quotes and insight, although they did not witness the crime nor speak in the capacity of an expert or official (e.g. police, prosecutor). The victim herself was not interviewed and one police officer quoted (a county chief deputy) provided limited information. He only stated that the suspects had previously planned to commit the various offenses against Williams - a sign of premeditation. The chief deputy did not weighin on any possible bias motivations.

Much of the background information was retrieved from official criminal complaints filed by police. Those details, along with the family's allegations, were enough to incriminate the 
suspects in the public eye. Although the incident was not officially declared a hate crime by law enforcement and prosecutors at that particular moment, it looked a lot like one. The news media, actions of primary claims-makers, such as the Williams family, and the fact that the victim and suspects shared different racial identities insinuated bias motivation in the attacks. The criminal complaint capped off the general belief that the suspects targeted Williams because of her race. The official complaint stated that a woman, Karen Burton, cut Williams' ankle while saying, "That's what we do to niggers around here." However, the responding officers did not classify it as a hate crime in the actual report.

The Charleston Gazette's competitor, the Charleston Daily Mail, handled the story in a similarly aggressive fashion. Both the Gazette and the Daily Mail are the largest daily newspapers in West Virginia and are located about an hour north from the Logan County crime scene. The Daily Mail published three different articles on its first day (Sept. 12, 2007) covering the case. Those articles entailed: 1) a reaction piece quoting the victim's neighbors as well as residents living near the crime scene, 2) an account by the victim's mother, 3) an analysis of the national media coverage and the potential negative perceptions this created for the state of West Virginia.

Headlines to the Daily Mail stories included, "Neighbors say abuse victim was 'very trusting," "Mother says victim didn’t know her alleged tormentors," and "Unwanted light shines on W.Va., Shocking events in Logan County attract national attention.” Words and phrases such as "outrage," "shocking" and "horror movie" appear predominantly throughout these articles.

While the victim exhibited impressionable, prey-like characteristics in these news reports, the suspects were instantly vilified in the public arena. Television newscasts and print media repeatedly displayed their emotionless mug shots. The Smoking Gun, a popular website devoted 
to celebrity scandals and arrests, featured the case as its main story less than 12 hours after the news first broke. It furnished online the suspects' photos, official criminal complaints and the headline "Six held in West Virginia torture horror." Furthermore, NBC Nightly News dedicated several minutes of a broadcast to the crime and CNN covered it as a top story (Wise 2007).

The public vilification of the suspects did not stop there. Local police officers and the head Logan County prosecutor, Brian Abraham, acknowledged they were "familiar" with all six suspects and their criminal histories. Neighbors fed the media with anecdotes about how they steered clear of these individuals because of their bad reputations. One couple called them a "rowdy bunch" that blared music nonstop, sometimes for days on end. Those neighbors were astonished to find out the suspects weren't already in jail when the crime occurred (Mohajer 2007). Published descriptions of the crime scene - the mobile home and its property - did the suspects no favors, either. Media reports mentioned empty beer cans, a rusting shopping cart and other unsightly litter outside the mobile home. Within a few days that the news broke, aspects of the suspects' lives underwent scrutiny in the media, from blasting loud music to having unkempt property.

Journalists also publicized the lengthy rap sheets of Williams' attackers. Collectively, the six suspects had been charged 108 times for various offenses, mostly violent, from 1991 to 2007 (Mohajer 2007). One of the suspects, Frankie Brewster, had served five years in prison for shooting to death the 84-year-old mother of her live-in boyfriend. News reports indicated that her son, Bobby, shot and killed that live-in boyfriend in 1998. Bobby was a teenager at the time and did not serve time in prison. As an adult, Bobby had racked up charges from brandishing a deadly weapon to obstructing an officer, domestic assault and domestic battery. The other four suspects had their brushes with the law, as well. Karen Burton had been arrested and charged 
with battery and assault of a police officer, disorderly conduct, public intoxication and trespassing. Both Alisha Burton and George Messer had faced indictment for burglary and firstdegree robbery after breaking into a woman's home in 2006. Danny Combs spent a few months in jail for daytime burglary, unlawful/malicious wounding and domestic battery.

Simply put, these six individuals were established offenders, a notorious crew locally. Within one week of the incident, the media framed this story by portraying Williams as a helpless, innocent victim and the six suspects as an unsavory predatory bunch.

Despite this packaged tale of innocent and evil, officials wrestled with the legal definition of hate crime when it came time to consider such charges. Only one of Williams' six attackers was ultimately charged and convicted under West Virginia's bias crime statute. As discussed earlier in this paper, state hate crime laws often vary from border to border and from the FBI's definition. In West Virginia, "All persons within the boundaries of the state have the right to be free from any violence, or intimidation by threat of violence, committed against their persons or property because of their race, color, religion, ancestry, national origin, political affiliation or sex (West Virginia State Code: §61-6-21).”

Prosecutors alleged that Karen Burton stabbed Williams in the ankle while saying, "This is what we do to niggers down here." Burton did not deny these abuses and pleaded guilty to malicious wounding, assault and violating Williams' civil rights (Mohajer 2008). The other five suspects apparently did not attack Williams due to bias, based on the state criminal charges levied. Within days of the arrests, Charles Miller, the U.S. attorney for the Southern District of West Virginia, announced no federal hate crime charges would be filed in the case.

Beyond Burton's involvement and guilty plea, several factors muddied the overall hate crime debate. As the story unfolded in its initial week, it was learned that Williams was involved 
in a romantic relationship with Bobby Brewster and that she knew her attackers. Neighbors and authorities said that relationship was destructive. Williams lived in Ohio when she decided to visit Logan County to meet a man through a telephone dating service (Harki 2007). When she arrived, she met Bobby Brewster. Two months prior to the incident, he was charged with domestic battery and domestic assault for striking and verbally threatening Williams at the same mobile home. In another occurrence a month later, Williams ran to a neighbor of the Brewsters' for help. She told the neighbor that she had been threatened with a gun and needed to leave town. Investigators viewed this as not a random attack because the victim and offenders knew each other, which chipped away at the hate crime argument. The Charleston Gazette reported, "The picture slowly being revealed is one of a woman abused not necessarily because of her race, but because of her relationship with one of her alleged attackers."

Still, the hate crime discussion permeated in the public arena leading up to the criminal trials of the accused. Claims-makers kept this debate alive by lambasting public officials' decision to not charge all six suspects with hate crimes. As Best (1999) asserts, claims-makers are the promoters, activists, professional experts, and spokespersons involved in forwarding specific claims about a social condition. In this case, the alleged problem, or social condition, was racial injustice in West Virginia. Victims and advocates serve as primary claims-makers, according to the Best framework. Meanwhile, the media can act as a secondary claims-maker by reworking, repeating, translating and transforming the claims of primary claims-makers.

Prominent civil rights activists, such as the Rev. Al Sharpton and Malik Shabazz, former leader of the New Black Panther Party, hosted rallies to drum up support for Williams. They utilized the news media in projecting their message and made public appearances in West Virginia and Washington, D.C. with the Williams' family. In newspaper reports, Shabazz 
described "racial imbalances" in West Virginia and claimed blacks were treated unfairly there by the whites in power. Their involvement led to a flurry of additional media content for the case. Before the criminal trials, Sharpton told the Charleston Gazette regarding the sole hate crime charge in the case, "I think that is good that we got one but she (Karen Burton) wasn't there hating by herself. They all should have been charged with a hate crime. I don't think one charge would have been filed had it not been for the public outcry (Harki 2008). "In the same article, Shabazz called the one hate crime charge "historical for West Virginia standards of justice."

All six suspects had gone to trial by mid-2008. Here are the results of their charges:

- Bobby Brewster: sexual assault, malicious assault, conspiracy to commit kidnapping, up to 40 years in prison.

- Frankie Brewster: second-degree sexual assault; 10 to 25 years.

- Karen Burton: hate crime and two assault charges; up to 30 years.

- Alisha Burton: kidnapping and assault; up to 10 years.

- Danny Combs: conspiracy to commit kidnapping, assault, sexual abuse, up to 20 years.

- George Messer: kidnapping, assault, up to 10 years.

- Linnie Burton Jr.: who was not initially charged in the case, battery, six-month suspended jail sentence and one year of supervised probation.

Despite only one hate crime conviction and the ambiguous nature of the event (from a bias motivation standpoint), police still view the Megan Williams case as a hate crime. Williams even recanted the whole story in October 2009 and claimed the kidnapping and abuse never took place. Williams' attorney said she concocted the story to enact revenge on her boyfriend, Bobby Brewster (Breen \& Leingang 2009). The head prosecutor, Brian Abraham, stood by the charges and convictions levied against her attackers and called the recanting an absurd publicity stunt. A 
month later, Williams changed her story again and told the Charleston Gazette that she was raped and tortured but not forced to eat animal feces and drink from a toilet (Harki 2009). Even Frankie Brewster, in an interview behind bars, said the abuse did happen - not due to Williams' race or her relationship to Bobby Brewster, but because she had stolen some money and food stamps (Aaron 2009).

Yet, partly due to media framing and the influence of claims-makers, it persists as a prototypical hate crime case. From the time the news first broke in September 2007 through the end of that year, the Charleston Gazette and the Charleston Daily Mail collectively published 161 articles on the case, not to mention the other forms of national and local media (television, radio, weekly newspapers) that covered it. The region was bombarded with story after story questioning the hate crime element of the torture case. In the public eye, it became a hate crime case even though only one person was charged and convicted. The construction of other social problems can be related to this particular case. In examining the construction of child abuse, Johnson (2008) declared that "Eliciting emotion often paves the way for action. Negative emotions may be aroused by detailing the gruesome facts of the injury, or the consequences of the abuse, or even the circumstances surrounding the investigation." Local media covered those aspects in detail.

The Williams case further stands out for the following reasons: (1) the extreme behaviors exhibited in the crime, (2) the victim and offenders shared different racial identities, (3) there were multiple offenders, (4) local and national media covered it as a hate crime, (5) the offenses appeared to involve some level of premeditation, (6) it occurred in a rural, predominantly white location, and (7) forcing someone to drink from a toilet, lick blood and eat animal waste doesn't happen too often. 


\section{STUDY DESIGN AND METHODS}

This research draws from multiple sources of data, including a random sample of official police records covering 2008 and a focus group interview of four patrol officers and a lieutenant representing the agency studied. In this section, I will break down how this data was gathered and analyzed for a separate assessment dedicated to hate crime classification error, and will also illustrate how I treated the data for this study.

\section{Police Records}

A research team (which included this author) spent the summer of 2010 collecting data for a study exploring the issue of classification error in the national FBI hate crime statistics (Nolan et al. 2011). The report gauged the amount of hate crime reporting overcounts and undercounts, as well as officer attitudes toward hate crimes, pertaining to one particular police department in a Mid-Atlantic state. The Justice Research and Statistics Association (JRSA) funded the project as the research team, comprised of statistical researchers from a state government agency and members of a university sociology department, fulfilled the intent of the study.

For potential data sources, we gained permission from four local police agencies to review a random sample of their annual 2008 crime reports. With each agency sample, we would review cases to see if bias-motivation played a factor in any incident or offense, regardless of whether it was classified as a hate crime by police. After initial onsite reviews of files at the four agencies, we narrowed the scope to one department after recognizing the low volume but geographical distribution of hate crimes within that state. Only 60 of the 92,939 incidents reported by police in this Mid-Atlantic state were classified as hate crimes in 2008. Because of 
the low figure, we decided to focus solely on the Mountainville PD, which represents a diverse community and one of the largest police departments in its state.

To start the study, data files from the National Incident-Based Reporting System (NIBRS) were used to partition records, calculate sample size, and randomly select records for review. From partitioned data files, cases were randomly selected for review in the statistical program SPSS. Researchers then provided the agency's records division supervisor with the list of randomly generated incident numbers and scheduled an on-site visit to review the physical hardcopies of each case. A team of eight reviewers spent two days reading and assessing these files at the agency's headquarters in the summer of 2010.

Before reviewing the records onsite, we underwent a one-day training session devoted to hate crime identification. The first author (Nolan) of that study, a renowned hate crimes expert, provided us with information on understanding and clarifying the challenges associated with bias crime classification. Emphasis was placed on the various definitions of hate crimes, including the statistical definition established by the FBI and the local criminal statute. Reviewers were also trained to identify bias indicators, which are other clues that law enforcement can seek in determining if a case should be classified a hate crime. Indicators include objective facts, circumstances, or patterns attending a criminal act, which suggest that the offender's actions were motivated, in whole or in part, by any form of bias (U.S. Department of Justice, 2009). Examples of bias indicators can include:

- Words, symbols or acts that may be offensive to an identifiable group were used by the offender (e.g. burning cross, painted swastika or derogatory slurs)

- The victim and the offender are members of different social identity-based groups, such as racial or religious groups. 
- There has been recent tension or hostility between the victim's group and another group (e.g. aftermath of $9 / 11)$.

- Location of the incident (e.g. near a gay bar or a place of worship).

- The crime coincides with a specific holiday or date of significance (e.g., Martin Luther King Day, Rosh Hashanah, Adolf Hitler's birthday).

- The victim is a member of a group that is overwhelmingly outnumbered by members of another group in the area where the incident occurred.

- The victim was engaged in activities promoting his or her group.

- The offender was previously involved in a similar incident or is a member of, or associates with members of, an organized hate group (e.g. Ku Klux Klan, Aryan Nation).

Each police report entailed specific information about the incident (e.g. victim, suspect, time, location), as well as a narrative, a summary in the responding officer's own words detailing what had transpired. In reviewing each record, researchers set out to see if hate or bias emerged as a possible motivating factor in the reported incident. Cases ran the whole gamut of criminal acts, ranging from domestic assault to breaking-and-entering. To detect bias, reviewers applied the statistical and legal hate crime definitions to each case and referred to a list of bias crime indicators. If a reviewer found elements of bias in a report, that file was flagged for a further discussion among team members.

Once finished reading a report, researchers recorded it as a specific crime-type category under two distinct headings: 'original classification' and 'recommended classification.' Making these classifications allowed us to measure the perceived error rate in the department's hate crime reporting and keep score of bias-related events. Based partly on the NIBRS model, 
categories were utilized for the classifications: Group A offenses, Group A hate crimes, Other

Group A offenses, Other Group A hate crimes, Group B arrests, General Incidents, Hate

Incidents and Unfounded (see following table for description of categories).

Key Terms and Definitions

The definitions of the crime categories as established for the purposes of this study are included below along with statistical terms used frequently throughout this report.

Group A Offenses. Those offenses most likely to occur in situations where bias is a motivating factor. These offenses include all assaults (aggravated, simple, and intimidation), burglary/breaking and entering, destruction/damage/vandalism of property, and robbery.

Other Group A Offenses. All other crimes against person, property, or society for which incident reports are required to be submitted to NIBRS/WVIBRS. These offenses include arson, bribery,

counterfeiting/forgery, drug/narcotic offenses, embezzlement, extortion/blackmail, fraud offenses, gambling offenses, homicide offenses, kidnapping/abduction, larceny/theft offenses, motor vehicle theft, pornography/obscene

material, prostitution, forcible and nonforcible sex offenses, stolen property offenses, and weapon law violations.

Group B Offenses. This category includes those crimes that are only reported to NIBRS/WVIBRS when an official arrest is made. The offenses included are bad checks, curfew/loitering/vagrancy violations, disorderly conduct, driving under the influence, drunkenness, nonviolent family offenses, liquor law violations, peeping tom, runaway, trespassing, and all other offenses not defined as Group A.

General Incidents. This category includes all reports filed by the police for noncriminal matters, such as suspicious person investigations, false burglary alarms, and community problems/disputes.

Hate Crimes. As defined by the FBI, "a criminal offense committed against a person or property which is motivated, in whole or in part, by the offender's bias against a race, religion, disability, ethnic/national origin group, or sexual orientation group." West Virginia also recognizes gender and political affiliation as protected classes against bias.

Hate Incident. While not a criminal offense, an incident that is reported to law enforcement and involves characteristics of bias against a race, religion, disability, ethnic/national group, or sexual orientation group. West Virginia also recognizes gender and political affiliation as protected classes against bias.

Unfounded. Crimes that were reported to law enforcement but were subsequently determined by police to be false or baseless.

Source: Nolan et al., 2011

On forms created and used by the research team, we recorded the incident number for each case, offered additional comments when necessary and classified the report into the appropriate category. Under a column designated 'original classification,' the reviewer would note which category fit the case based exclusively on the officer's discretion. Consider the 
following fictitious scenario: A Jewish family reports to police that someone spray-painted a swastika onto their garage door. The responding officer does not recognize this as a hate crime. Rather, he reports it as a simple destruction of property case. Under 'original classification,' a reviewer would label this a Group A offense because it represents the officer's official decision. The 'recommended classification,' on the other hand, reflects what the reviewer thinks the incident should be classified as. In this case, the recommended classification would be a Group A hate crime due to the bias elements accompanying the offense (destruction of property). The painting of a swastika, an offensive symbol to Jews, indicates a possible hate crime according to the guidelines established by the research team. This approach helped us detect which hate crimes we felt police 'missed' or overreported.

To ensure reliability between reviewers, a procedure for the reassessment of records was established. Ten percent of cases from each crime category were randomly chosen for a second review by a different researcher. In instances where a classification error was suspected, the group collectively decided upon the recommended classification. Since only four cases in the sample were originally classified as hate crimes by police, all of those cases were reviewed by the team as a group as well.

Ultimately, the Nolan (2011) study identified seven records out of the 502 in the sample as hate crime classification errors, including two overcounts and five undercounts. Given our own rules of classification, that means that five cases could also be hate crimes, though they were not originally identified as such by police. It was then estimated that 50 errors in classifying bias-motivated incidents were contained in the entire population of Mountainville PD's 11,667 records for 2008. 
For purposes of this study, I will utilize an open-coding technique central to the grounded theory approach (Corbin and Strauss 1990) to reevaluate the official police reports in the sample. The reports will include only those that the Mountainville PD classified as hate crimes and those that auditors believed could be hate crimes. I will conduct a line-by-line examination of the reports, primarily the narratives, to break down, compare, conceptualize and categorize new data. Since its introduction in the 1960s, grounded theory offers methodical procedures such as opencoding that can unravel explanations of social phenomena (Corbin and Strauss 1990). Examining these records through the grounded theory lens shall reveal information regarding hate crime policing and classification on the part of law enforcement.

\section{Focus Group}

Following the onsite reviews for the Nolan study, the research team arranged a focus group interview with four Mountainville PD patrol officers and a lieutenant. The patrol division of the Mountainville PD is the 'backbone' of the agency, according to its official Web site. The division consists of four shifts - each supervised by a lieutenant and three sergeants. Patrol officers typically work 12-hour shifts and are usually the first responders to a variety of calls ranging from violent crimes to parking issues. In 2008, the Mountainville patrol division responded to more than 70,000 emergency 911 calls. Since patrol officers are typically the first responders at a scene, they wield the power in determining whether a situation was motivated by bias. Gathering input from these officers would be valuable as they are second in line (following the crime victim) in the hate crime reporting process. If responding to a potential hate crime, they can classify the event as bias-motivated and it would continue to make its way through a funnel 
that may ultimately reach the official FBI hate crime database. Patrol officers can also choose not to report an incident as a hate crime and the issue would likely die instantly.

Researchers contacted a Mountainville lieutenant a few days after their onsite review to request a focus group session in an attempt to add a qualitative component to the study. The lieutenant accepted our request and asked patrol officers if they wanted to participate. Only four agreed to the interview, which took place in a briefing room of the agency's headquarters. One strength of this focus group is that the officers volunteered their time to discuss hate crimes, meaning they probably held strong feelings one way or another about the issue. Officers with indifferent attitudes about hate crimes may not have participated.

The session lasted approximately an hour-and-a-half. Questions and topics were generated by Nolan and myself, who led the discussion. The participants were not informed of any questions prior to the interview. They only knew that the general theme for the session was hate crimes.

Before the session, we distributed documents containing the federal and state hate crime definitions in order to give officers a refresher on the topic, if needed. Participants were assured that their identities would remain anonymous (Note: In this report, their names have been omitted) and they also granted us permission to tape the interview with a cassette recorder. Not only does anonymity protect the identities of the officers, but it provided a relaxed setting in which they contributed freely. One potential drawback is that their lieutenant (a superior) also participated in the discussion and her presence may have affected responses and behaviors during the interview. After a brief introduction, we then provided the officers with four scenarios - actual cases from their own department that we identified as possible bias crimes and incidents - to gauge their responses and attitudes toward hate crimes and these real situations. Officers 
read copies of the official narratives to these cases and weighed-in on whether they thought bias played a factor. Only one case was discussed at a time, and researchers did not disclose if they believed a case should have been classified as a hate crime.

Follow-up questions, both predetermined and off-the-cuff, included:

- What factors make investigating hate crime cases more or less challenging than other types of crimes?

- What would be the most important characteristics of a crime to determine whether or not it was a hate crime? In other words, what indicators would make it a clear-cut hate crime?

- How are officers trained to deal with hate crimes?

- What do most police officers say or think about hate crimes as far as it being a special category?

- How do you see hate crime as a different type of crime?

- Can you guys think of any hate crimes that have occurred in the community?

- What's the most likely kind of hate crime that would occur here (e.g. anti-gay, anti-race, anti-gender)?

- How are hate crime offenders treated differently (e.g. Do they get more jail time?)?

- What would you do in the community if a hate crime occurred?

After a productive session, reviewers requested another focus group interview with the agency, this time with the department's detective unit which follows up on cases that require further investigation. This request, however, was not granted due to heavy workloads of the detectives.

While the focus group served as a secondary function of the Nolan study, it will serve a more prominent role in the findings of this paper. I will delve deeper into the interview 
transcript, as only a brief summary of the focus group made it into the Nolan report. Like my examination of the police reports, I will again apply an open-coding technique to the interview transcript. By using the coding process and a more meticulous qualitative content analysis, I will shed light on how police see or don't see hate crimes, as well as organizational factors that may bear influence on their behaviors, based on the officers' words verbatim. As touched upon earlier, the grounded theory approach has pushed key themes, commonalities and contrasting views to the forefront of this research. In analyzing the focus group transcript, several themes emerged, which included officers arguing that only unambiguous atrocities are hate crimes, blaming bias behaviors on some other triggering event (e.g. drugs, disputes, responseretaliation), and agreeing with one another most of the time.

As an original participant in the gathering of these data, I bring a working familiarity with these materials already. Because of my role in the Nolan report, I can be considered an insider. At the same time, I hope to analyze these data in a nonpartisan fashion by relating to sociological concepts discussed in the literature section and recognizing that our initial work was guided by a set of constructed classification/measurement criteria in itself. (Our own findings fit into the debate of classification and measurement among researchers and to a lesser degree, organizations) Collectively, these materials will produce an analysis that explains how police see and don't see hate crimes.

\section{RESULTS}

\section{Hate crimes are extraordinary}

Police are more likely to label a situation a hate crime if it contains extraordinary properties that rarely emerge in their everyday routines. As with most professions, police expect certain things to happen on the job. They deal with the same characters, work in the same 
neighborhoods and respond to similar calls. Over time, officers develop a routine and a perception of what's ordinary and extraordinary. It appears that Mountainville Police are hesitant to classify ordinary crimes as hate. If a bias-tinged event blends in with the minutiae of police work and the majority of calls handled (e.g. domestic disputes, fights, drug-related incidents, burglaries), it does not stand out as a hate crime. But if that bias event involves rare or extraordinary elements (e.g. murder, torture), it shatters the routine of a police officer and he or she is more inclined to classify it as a hate crime.

Here I will examine cases identified by either researchers or police as bias crimes from a random sample of Mountainville Police Department records spanning the year 2008. In the following section, I shall highlight the extraordinary and ordinary properties that guide law enforcement's perception of hate crimes. By applying open-coding techniques central to the grounded theory approach, as discussed in the methods section, I identified "extraordinary" and "ordinary" properties contained in the content (police reports, focus group interview) for this study.

Extraordinary properties include: 1) extreme behavior, 2) premeditation, 3) sympathetic victim, 4) multiple offenders, 5) media coverage/framing, 6) significant harm.

By contrast, ordinary properties include: 1) routine offenses (e.g. simple assaults, neighborhood disputes), 2) response/retaliation, 3) unsympathetic victim, 4) single offender, 5) minimal or no media coverage, 6) minimal harm. 


\begin{tabular}{|c|l|}
\hline Extraordinary properties & Ordinary properties \\
\hline Extreme behavior (e.g. extreme & Routine offenses (e.g. simple \\
\hline violence, torture, cross burnings) & assaults, neighborhood disputes) \\
\hline Premeditation & Response/Retaliation \\
\hline Sympathetic victim & Unsympathetic victim \\
\hline Multiple offenders & Single offender \\
\hline Media coverage/framing & No media coverage \\
\hline Significant harm & Minimal harm \\
\hline
\end{tabular}

\section{Extreme Behavior vs. Routine Offenses}

Cases considered hate crime undercounts by researchers in the Mountainville sample and criticized by police as 'non-hate crimes' involved low-level assaults. These represent commonplace, routine offenses that police handle quite frequently. In these undercounted cases, no one was hurt to the degree that they required hospitalization. Since the injuries were not severe, these cases lacked any properties that stood out as extreme or unique to police officers. One victim, a black woman, was 'bumped' by a white man on the street in one incident. In another case, a black male juvenile punched, grabbed and threw rocks at a white woman who did not exhibit any visible signs of abuse. The alleged suspect couldn't even be found. A third incident entailed a mother grabbing her daughter by the throat and destroying her property, supposedly over her disapproval of the daughter's relationship with a black man. These were not 
unspeakable acts of violence. They gained zero media attention and did not rile up the community. Police did not consider the different races of the victims and offenders as an influencing factor in these crimes, which were rather routine offenses that officers deal with every day. Racial language was used in some instances, but even that aspect alone did not stand out to officers.

On the other hand, the two cases designated by police as hate crimes in this study involved extreme behavior - three assailants battered a man with a baseball bat and knocked him unconscious before sexually assaulting him, and a group of 10 female juveniles jumped and bloodied another female juvenile who was waiting for a bus. Those incidents are not everyday occurrences in the jurisdiction of Mountainville.

Extreme behavior personifies the two most publicized hate crimes in recent U.S. history the slayings of James Byrd and Matthew Shepard. If you recall from earlier in this paper, Byrd was dragged to death by a pickup truck and Shepard was tied to a fence post and left for dead. Extreme behavior is present in the following recollection from a Mountainville officer regarding a black-on-white assault (this incident was not part of the sample and allegedly occurred several years ago):

"We had a white kid playing basketball and some black kids came down and racially slurred him, beat him up, took his ball and pissed all over him. There were four of them-eightor 10-years-old. They weren't very old. They beat him up and was calling him 'cracker' and pissed all over him, took his ball and walked off."

Urinating on someone constitutes as extreme behavior. Calling that person a derogatory racial name in the process makes it a hate crime. Focus group participants believed that incident should have been classified as a hate crime, although they said the responding officer did not 
mark it as one. Extreme behavior is not limited to violence, either. In the focus group interview, officers identified symbolic acts such as cross-burnings and the spray-painting of slurs deemed offensive to a particular group as hate crimes. Some actions leave a visual impact and do not occur as often as, say, an argument or physical altercation.

The following dialogue supports this statement:

Interviewer: "What are the other indicators that would clearly say to you that a hate crime has occurred?"

Officer 1: "If I find a gay guy lying in the middle of the street and he's been dragged up and down through here. And there's a good chance he didn't live here. He's from Colorado or somewhere and they just picked him up because he's gay."

Officer3: "If you put up graffiti or catch a synagogue on fire."

Officer 2: "Spray-paint racial slurs on somebody, or knock them out and spray-paint slurs around him."

Officer 1: "Or put a swastika on his head."

Because police associate extreme behavior with hate crime, the frequency of these events is rare. Each officer participating in the study said they had never handled a hate crime in their years of policing. They believe, however, that they could properly identify and investigate one.

Officers interviewed also considered random attacks and incidents involving individuals who do not know each other as extreme behavior. Domestic incidents, for example, always involve victims and offenders who share some sort of preexisting relationship, neighborhood disputes involve neighbors, drug-related crimes involve sellers and buyers, and so on. Therefore, it is rather routine for police to handle a call in which the parties involved are connected. 
Police were asked by interviewers, "What would be the most important characteristics of a crime to determine whether or not it was a hate crime? In other words, what indicators would make it a clear-cut hate crime?" One officer responded,

“They don't know each other. The victim's innocent. You have two different parties that don't know each other, and that's(bias) the only reason they got into a fight."

\section{Premeditation vs. Response/Retaliation}

Premeditation, as it pertains to crime, is the act of planning and carrying out an offense. Premeditation is used by most legal systems as a formula to differentiate between the severities of offenses. The Virginia Supreme Court, in the 1817 case of King v. Commonwealth, reasoned that premeditated first-degree murder meant that the killer had to formulate a plan to kill before carrying it out (Pauley 1999). Even when applied to other crimes, premeditation is considered more serious than an offense committed out of passion or without initial intent. In the Williams case, it appeared that premeditation existed with the tying up of a woman, holding her captive and forcing her to engage in unusual acts of humiliation. Early media accounts theorized that Williams was kidnapped and tortured because of her race (an argument that later become rickety).

In our focus group interview, participating officers asserted that premeditation must exist in a hate crime. Through the eyes of Mountainville police, people engage in cognitive processes - the intention to commit an offense fueled by his or her bias -- before committing that offense. The offender targets a certain group (e.g. homosexuals, blacks, Muslims) beacuase of their personal hatred for that group. One officer remarked: 
"Hate crime has to be premeditated. They have to get in their truck and plan to go mess with whoever they want to go mess with. That's the only reason. Not because they hit my car or screwed my old lady, none of that. We'll get into a car and go find a gay guy or black guy or Jew and that's the only reason we went to do what we did."

Referring to the case in which a white man bumped into a black woman and called her 'nigger,' police argued it was not bias-motivated because it lacked premeditation. One officer stated that verbalizing racial slurs and epithets does not necessarily make an action a hate crime. Another officer said he would have classified this situation as a hate crime only if he could prove that the offender left his home with the intention of fighting a black person. In this case, the victim and offender encountered one another by chance. Words were exchanged about the dogs and both individuals grew angry and irritated. In essence, police view premeditation as an extraordinary value. What happened here was a random, off-the-cuff exchange on the street - a rather ordinary event.

Rather than premeditation, this incident was interpreted as a response/retaliation offense. Nolan et al. (2004) describes response/retaliation events as offenses that are first triggered by something other than bias, but it is bias that exacerbates the incident and fuels the crime that ultimately occurs. For example, two motorists - one white and one black -- engage in an argument over a parking space that develops into an assault. One can claim that the fight was incited by the parking space, not bias. But if the argument escalates into a fight because of the real or perceived racial differences between the drivers, this event can now be classified as a hate crime, according to statistical and legal definitions. Nolan calls these situations ambiguous hate crimes. The triggering event muddies the picture and police fail to see bias as an issue if an alternative explanation exists for a crime. Therefore, an incident in which an offender responds 
or retaliates to a triggering event is viewed as ordinary to police compared to a crime that is premeditated.

\section{Sympathetic Victim vs. Unsympathetic Victim}

James Byrd is a sympathetic victim. By all accounts, he did nothing to provoke or anger the three men who wound up taking his life. They targeted him solely on the color of his skin. Based on the media framework, Byrd's innocence - and simply being in the wrong place at the wrong time - added dimensions of sympathy to the story.

As discussed earlier, Megan Williams, though not much was known publicly about her in the beginning, was seen as a defenseless victim due to her reported learning disability, small physical build and being outnumbered by her assailants one-to-six.

Crimes are easier to define as heinous if the victim is sympathetic, helpless and innocent. Throughout the victims' rights movements of the $20^{\text {th }}$ century, advocates typified "ideal victims" as vulnerable, harmless innocents exploited by dangerous, predatory deviants (Best 1999).

Not all crimes feature the storybook victim and villain. Sometimes victims get blamed for the crimes that happen to them. These victims do not fit the mold of the innocent victim; they have usually done something to cause the crime. In three cases presented to the focus group, police viewed the victims with a critical eye. They theorized that these victims either said or did something to provoke the other person to attack them.

Police see a majority of the residents they serve through a negative lens. One officer claimed that most residents they deal with have a third- or fifth-grade education. The focus group interview revealed that officers distrust most people they encounter on the job, even complainants. Police exhibited an 'Us versus Them' mentality, in which they and their 
colleagues play the role of 'Us' and everyone else plays 'Them.' Unless someone strikes them as undoubtedly innocent, they will treat everyone - victims included - with skepticism. One officer spoke about his experiences talking to victims and suspects:

"If you can get a story from the victim and a story from the suspect, the truth is going to fall somewhere in the middle of what both of them are saying."

Another officer, expressing his distrust of others, followed-up with:

"Unless you have an innocent third party giving you a statement. Or maybe a retired cop sitting across the street watching. Even then, I wouldn't even trust him."

Later in the interview, another officer shared his thoughts on responding to a routine call:

"You can pretty well tell 70 percent of the time when you get dispatched, you already know every word that's going to come out of their mouth before you get there and 99 percent is going to be a lie."

The lieutenant participating in the focus group explained that some people can avoid becoming a crime victim. Those are unsympathetic victims - individuals who knowingly enter violent, drug and crime-infested areas and associate themselves with criminals. On the other hand, there are sympathetic victims. In the context of hate crime, the lieutenant said,

“You can't protect yourself by walking down the street and being female, or being black, or being white, or being different."

\section{Multiple Offenders vs. Single Offender}


In this study, the two cases that researchers felt police correctly identified as hate crimes involved a single victim and multiple offenders. By contrast, the cases that involved one victim and one offender did not gain the focus group officers' approval for hate crime.

Gang-like violence, or instances where a group of individuals attack one person, is not too prevalent in Mountainville - a relatively small municipality that pales in stature not only to major metropolitans like Los Angeles and Chicago, but cities such as Columbia, Missouri and

Boulder, Colorado - when compared to other areas. Attacks unleashed by multiple offenders are associated more with cities and urban environments; they're uncommon, or extraordinary, in a place like Mountainville.

In their focus group interview of officers, researchers kept asking different variations of 'What's a hate crime?' In most scenarios derived by the police officers, an attack or offense involving a 'group' or 'gang' of people usually constituted a hate crime. One officer said 'four boys jumping out of a pickup truck' in a bias-related incident would lead police to consider hate crime. Another officer expounding on his colleague's statement:

"Like he said, you got a truck from one of these rural counties come in here and four boys beat the crap out of a black boy, you probably got a hate crime."

\section{Media vs. No Media}

As indicated in the Megan Williams section, the news media plays a substantial role in framing hate crime and serves as a secondary claims-maker in the construction of social problems. When media covers an event as a hate crime, it is extraordinary. Hate crimes in the news are a rare breed compared to other crimes. Robberies, sexual assaults and drug-related incidents dominate the crime news in print and broadcast. Those are perceived as common 
crimes. Taking those same situations and adding a hate crime element elevates them in the news world. If Megan Williams was sexually assaulted, but did not endure any of the other abuse or torture or alleged racial slurs, her story may not have made headlines. The hate crime aspect persisted as the dominant theme throughout the media's coverage of the case. News organizations frame stories by presenting information as facts to the public. The media initially framed the Williams case as a hate crime because of the different racial identities, the involvement of claims-makers and the police report detailing Karen Burton's use of a racial slur.

One officer in the focus group attested to the notion that the typical hate crime is one that is covered by the news media.

"The hate crimes you do see, they're ones that make national headlines. There's a clear separation between the two parties. Like that guy (James Byrd) who was dragged to death in Texas. Those boys didn't know him from Adam. It was clearly apparent they just came down there, found him walking on a country road, hooked him up and drug him down the street."

Without media coverage, a hate crime case is more likely to fall by the wayside. If it remains in the public eye and is framed as a hate crime, police may be more inclined to identify an event as bias-motivated. Framing Megan Williams as a sexual assault case and nothing more leaves it at that. The police participating in the focus group interview would not have specifically referenced it in our discussion of hate crimes.

\section{Significant Harm versus Minimal Harm}

The degree of harm inflicted upon the victim serves as an indicator as to whether police will classify an incident as a hate crime. In several of the cases in which the focus group participants did not see a hate crime, harm and physically injury was minimal. A body bump on 
the street does not translate into significant harm. In another report, a man was bloodied, knocked into unconsciousness and sexually assaulted. Police saw that incident as a hate crime.

\section{Case-by-Case}

In addition to a transcript of Mountainville police officers participating in a focus group interview, this report examines six official police reports from the sample of 502 that were either originally classified as hate crimes by police or recommended to be classified as hate crimes by researchers.

Throughout the next several pages, I will examine these six cases individually and present my findings for each. The original research team presented only possible hate crime undercounts to the officers during the focus group. They did not discuss any of the reports originally classified by police as hate crimes. Extraordinary and ordinary features can still be drawn from these reports, as they mirror the overall sentiment provided by the focus group participants.

Researchers agreed with the police department's original classification of the two hate crimes I am about to summarize and discuss.

Case 1: Police found a white male sprawled out on his front porch with his pants around his knees. An officer shined a light on him but he did not move or speak. The male finally responded when the officer approached and spoke to him. Blood seeped out of the man's nose and head. The officer noticed a laceration on his upper left arm.

The man said he was sitting on his front porch when he heard a noise coming from the back of the house. After walking around the house to investigate the ruckus, he saw three men of 
unknown races wearing masks. The men called the victim by his name and charged at him while yelling 'faggot' and 'queer.' One of the assailants wielded a baseball bat and struck the victim several times in the ribs while a second attacker punched him repeatedly in the head and face. The third suspect brandished a sharp object, believed to be a knife or broken bottle, and cut the victim's arm.

The victim told police he was knocked unconscious but woke up to find one of the males sexually assaulting him in the anus. During the sexual assault, the men kept calling him a 'faggot' and a 'queer.' Afterwards, they fled from the backyard. An officer found an aluminum baseball bat under the victim's van.

Extraordinary properties outlined earlier - extreme behavior, premeditation, sympathetic victim, multiple offenders and significant harm - are present in this case. For reasons unknown, the local media either did not know about the incident or chose not to report it. The assailants appeared on scene in masks and wielding weapons, indicators that they planned the attack before carrying it out. Though the report draws solely from the officer's perspective and the victim's statement, it does not portray the victim in a negative light. Based on the narrative, he was simply minding his business by sitting on his front porch before investigating a noise. The emerging details of the physical attack and sexual assault embody 'extreme behavior.'

Case 2: A white female juvenile was sitting with her friend on the sidewalk waiting for a bus when a group of about 10 black female juveniles walked toward her and acted like they were going to punch her. The victim asked one of the girls, 'Why were you getting ready to hit me?' At that moment, the black females jumped the white girl, punching her several times in the face and dragging her across the parking lot. The offenders then fled to a nearby cinema. 
The only true indicators of bias in this example are the different races of the victim and offenders. Due to the lack of further information in the report (e.g. motive, whether racial language was used), it is difficult for an outsider to determine if this was a hate crime. Because police marked it as bias-motivated, the research team erred on the side of the officer. This incident appeared premeditated and involved multiple offenders and a sympathetic victim (who did not appear to provoke the attack based on the police report). The offenders appeared to embark on 'extreme behavior' by inflicting a considerable amount of physical harm on the victim, who vastly outnumbered, punched repeatedly and dragged around a parking lot.

The following scenarios stem from cases that auditors believe should have been counted as hate crimes but were not:

Case 3: The bumping example presented at the beginning of this report (White man 'body-bumps' a black woman and calls her 'nigger.')

This case seems like a routine occurrence in the eyes of Mountainville police officers, as it contains the ordinary properties outlined previously. Also, the mere usage of racial slurs and derogatory bias remarks does not constitute a hate crime, based on officers' beliefs. Slurs and name-calling actually fit the 'ordinary' category in a police officer's day. A Mountainville PD lieutenant commented that, "You get slurs on every call that you go on." Another officer recalled how he responded to recurring domestic dispute calls at the same residence. He claimed that the man and woman living there called each other derogatory racial names but that was not the reason for their fights.

"I remember there was a couple down on Sixth Street that sold drugs and they were a white guy married to a black woman. They had domestics every day and you'd go into their 
house and she'd call him the ' $n$ word' and he'd call her 'n lover.' Would that make the fight racially-motivated? They loved each other. That's how they talked to each other."

Another officer stated:

"Anytime someone calls someone else a racial slur, then we're going to have hundreds of hate crimes, you know?"

To Mountainville police, the white man's hurling of a racial slur at a black woman does not raise red flags as a potential hate crime. Officers stated that the offender's use of the 'n-word' may not necessarily make him racist. One officer explained that the man just 'ran his mouth and was being angry.' As discussed earlier, the officers see this as a response/retaliation event and not a premeditated attack. There's a reasonable explanation for the offender's actions against the woman that does not include racial bias. Another officer suggested checking the offender's criminal history to see if he's exhibited bias behaviors in the past. If so, then it could gain leverage as a hate crime in the eyes of police.

The offender's 'bump' into the victim is not extreme behavior and requires minimal attention by law enforcement. The details in the report are not necessarily attention-grabbing as the officers swiftly refused to acknowledge it as potentially bias-motivated.

Case 4: A middle-aged white woman was walking her dog down the street when a black male juvenile spotted her and invited her onto his porch. After stepping onto the porch, the woman was grabbed, pushed and struck in the face by the male while he yelled 'racial comments' at her. When she walked away, the male chased her down the street and threw rocks at her. 
The victim told police she did not know the male nor the exact address of where the assault occurred. The responding officer scanned the area but could not locate the suspect. The offer noted in the report that the woman had no visible marks on her. No complaint was filed based on lack of suspect information.

Mountainville officers viewed Case 4 similarly to Case 3, as it contains ordinary instead of extraordinary elements. Although a black male unleashed 'racial comments' on a white female as he physically assaulted her, police do not see it as a hate crime. Collectively, the officers thought there was more to the story than what was captured in the police report. The officers expressed skepticism toward the victim by wondering, 'Why would a middle-aged white woman go onto a black male juvenile's porch?' Taking the reputation of the neighborhood into account (officers said it's a crime- and drug-infested part of town), they painted the woman as an unsympathetic victim. Here's dialogue between the focus group moderators and the officers concerning this report:

Interviewer: "So what do you guys think about this - a black male juvenile invites a white female onto the porch and starts grabbing at her, calling her racial slurs. Is this a hate crime?" Officer 4: "Not really. I'd have to ask her why she went up onto the porch to begin with." Officer 2: "If you know the area, there's more to it. She walked up onto the porch for a reason, they got into an argument."

Officer 1: "She was probably on the porch the day before and the day before that, too."

Officer 2: "She didn't walk up onto the porch in that area for no reason. In that area, both are probably arguing over drug money or something." 
Officer 4: 'Like they're saying, one thing you guys gotta realize is there's nobody in this city who just walks up on somebody's porch. This isn't Mayberry. You don't just walk up on somebody's porch to hang out with them."

As this exchange indicates, the officers ignore the claim that racial language accompanied the attack. They are more attentive to the mystery surrounding why she walked onto the porch in the first place. In their opinions, they suspect an argument or triggering event occurred between the two that caused the male to attack the female. Again, this would portray a response/retaliation type of offense, given that the incident even occurred at all. Racial bias does not play a role in this case, as police see an alternative reason for the offense. They figured the only way it could be considered a hate crime is if the boy's attack was premeditated out of hatred for white people. One officer stated:

"She's walking down the street and if this boy sees her and says, 'Hey, come over,' because he doesn't like white people and beats her ass when she gets on the porch, you'd have the intent beforehand."

They also downplayed it as a possible hate crime because of where it took place - a shady part of town familiar to police as a haven for drugs and fights. Perhaps if it occurred in a relatively quiet, upper-class neighborhood with little or no criminal activity, they would have a different take on it.

Case 5: A mother tried breaking into her daughter's residence by tearing through a locked screen door. She failed to gain entry into the home as the daughter observed from the inside. The mom had come to retrieve a Jeep she had given as a graduation present to her daughter. As the mom began removing items from the Jeep, the daughter came out to confront 
her. An argument ensued and, at some point, things turned physical when the mom grabbed her daughter by the throat.

When police arrived on the scene, the daughter told them that her mother's actions were rooted in anger over her becoming pregnant by a black man. Both the mother and daughter (or offender and victim, respectively) are white. Police were further told that the offender was "going through a bad divorce and is not in her right mind."

Officers rely on their own discretion to make arrests. In this case, the daughter asked the officer to not file a complaint. She also declined to provide a written statement. Before leaving the scene, the officer advised the daughter to obtain a protective order against her mother.

Again, focus group officers dismissed this report as a hate crime. Although the victim and offender share the same racial identity, the mother's actions were motivated in part by racial bias, one could argue. Elsewhere in the country, whites have been charged and convicted of hate crimes committed against other whites. In 2009, David Brown, 49, was convicted under North Carolina's "ethnic animosity" law after he fired a shotgun at his white neighbor, who dated a black woman. Brown reportedly had a history of making racial comments to the couple. He served nearly a year in jail (Zash 2009).

The officers thought the mother was responding or retaliating for reasons other than bias - like the fact that her daughter was pregnant to begin with. A police report such as the one filed for this case makes it challenging for others to determine - with certainty - that a hate crime occurred. Here, the responding officer recorded what the victim told him or her. The offender's account was not included in the narrative. The officer wrote down why the mother attacked the daughter from the daughter's point-of-view, which translates to 'Mom is angry because I'm pregnant with a black man's baby.' Officers acknowledged this shortfall. One of them stated: 
“Looking at this, that's one person's opinion of why she might be angry, because she's not married and she's pregnant. She believes it's because he's black. That's just the daughter's opinion of why mom's mad. She could be mad she's just pregnant. Mom didn't make any statements or anything. It's a domestic as far as I'm concerned."

Once again, response/retaliation could be attributed to this case. The officers see this as a domestic situation - a quarrel between family members that got out-of-hand and required law enforcement's involvement. It can be explained that domestic calls, which involve verbal or physical abuse between partners, relatives or cohabitants, are rather ordinary occurrences in the daily grind of police work. If the mother admitted that racial bias fueled her actions, then police might consider it a hate crime, one officer expressed:

“They're taking the initial report and just off of one person's theory of why she got beat up. I wouldn't mark the box (for hate crime). If mom says, 'I beat her up because she fucked a black guy and is having his kids and I don't like it, 'then yeah, that would be a hate crime."

The daughter's injuries were not severe; she did not need hospitalization nor did she want to file charges against her mother, making this even more ordinary. If the victim did not care to press charges against her mother, then police are likely to feel indifferent about it, as well. Unless an extraordinary occurrence, such as murder or an assault leading to unconsciousness or hospitalization, splashes into the picture, incidents like this are cast as commonplace and insignificant.

Case 6: Someone left a note in a hotel room that read, "Any female found in this room will be raped." No other information was available. Police filed this as a general incident report. 
This case was not presented at the focus group because it was discovered and classified by the research team as a hate crime afterward. Researchers believed it could be a hate crime for these reasons: 1) Leaving a threatening note could constitute intimidation (a criminal offense); and 2) The threat is not specific to one person. It targets a specific gender as a whole - all females. In the local jurisdiction, gender is a protected class under the hate crime statute.

The reporting officer may not have considered this a hate crime because he or she failed to see it as a crime at all because it was filed as a general incident report. The incident also lacked a physical victim. No specific individual was threatened with rape or actually raped. It lacks extraordinary properties; therefore, police likely view this as not a hate crime.

\section{$\underline{V}$ : CONCLUSION}

Through various approaches (i.e. grounded theory, social constructionist), this thesis explored how law enforcement officials in a small Mid-Atlantic city see and don't see hate crimes. It further identified factors that shape a police officer's beliefs on hate crimes. Notwithstanding the hate crime focus, this thesis examined how media framing, organizational behaviors and routines affect how professions treat perceived problems. As Garfinkel (1967) studied the roles and decision-making processes of jurors and Timmermans (2006) presented the routines of medical examiners classifying death, police have their own set of formal and informal codes when handling a potential hate crime. As described earlier in this study, police are expected to utilize a formal code for investigating hate crime. These formal guidelines are provided by definitions and statutes of hate crime on both the federal and local levels. The informal approach, however, is the one more frequently utilized by police. 
At the beginning of the focus group interview, researchers supplied handouts explaining the laws on hate crime, as well as the FBI's definition. Seemingly disinterested, the officers glanced at the documents and placed them aside within seconds. They did not refer to the handouts while discussing the cases within this study. Instead, they applied off-the-cuff thoughts on how they would typically respond to such scenarios. From their perspective, either one of two things must happen before they will consider classifying an incident or offense as a hate crime: 1) It must be a clear-cut, unambiguous event containing extraordinary properties, and 2) the offender admits that he or she committed a crime because of bias.

In assessing the first reason, the officers spoke about hate crimes as rare occurrences. None of the officers interviewed said they ever classified an offense as a hate crime. From their perspective, hate crimes involve such extraordinary and extreme properties that they rarely occur. Officers kept referring to landmark cases such as James Byrd and Megan Williams as undisputed hate crimes. Extreme cases, such as those, that are played out in the national media help define their perception of a hate crime. Several of these extraordinary properties must exist in order for police to classify it as a hate crime: 1) extreme behavior, 2) premeditation, 3) sympathetic victim, 4) multiple offenders, 5) the media frames it as a hate crime, 6) significant harm is inflicted upon the victim.

Because hate crimes are so rare in the eyes of police, it would require little or no investigation to determine if an incident fit the bill. Police see hate crimes through a black-andwhite scope. It either is a hate crime or not. There are no shades of gray. The 'motivated in whole or in part' portion of the FBI's hate crime definition does not apply to the real-time realities of police officers. There is no 'in part.' As one officer declared: 
"If it's a true hate crime, you're going to know it. There would be no doubt. There would be no question about it. If you wrote the report, it would be staring at you."

Another officer stated:

"I don't think it would be hard to investigate anything else because when you arrive on scene, it's going to be black and white. It's going to be there right in front of you. There's no doubts about what happened."

This indicates that police assume a 'I know it when I see it' attitude regarding hate crime. "I know it when I see it" was a phrase popularized by U.S. Supreme Court Justice Potter Stewart in 1964. In an attempt to explain pornography or obscene material, he said, "I shall not today attempt further to define the kinds of material I understand to be embraced...but I know it when I see it (Jacobellis v. Ohio, 378 U.S. 184, 197 (1964))." The quote encapsulates the difficulty in defining or classifying certain things. Much like obscenity, hate crimes pose challenges for the actors charged with defining and classifying the concept.

If police do not encounter an unambiguous "I know it when I see it" type of hate crime, an admission by the offender would help officers identify a hate crime, as well. Hate crime is such an abstract concept that these are the only two instances in which police would consider classifying an incident as bias-motivated. One officer said he would feel 'uncomfortable' labeling an event a hate crime unless the offender admitted to it. Police officers often deal with crimes in which they can gather concrete evidence. Crimes such as murder, assault and rape can be proven through physical evidence. But police can't prove with 100 percent certainty that a person committed a crime because of their personal feelings on race, sexual orientation, and so on. One officer stated, 
"I wouldn't feel comfortable checking that box unless I was on scene and the person I had in handcuffs or the person I was questioning for the crime said, 'Yeah, I beat him up because he's gay, because he's black..."

These hard-line stances on behalf of police clash with the leniency awarded by the federal hate crime definition. The FBI's 'in whole or in part' portion of the definition allows officers to record hate crimes even if they are ambiguous. But when situations are muddied by other factors or if an alternative explanation exists for the cause of a crime, police are less likely to ponder bias motivation. Throughout the focus group interview, officers offered alternative explanations for the cases presented to them. They blamed incidents because of their location (high crime neighborhoods) and other possible triggering factors (i.e. drugs, domestic disputes). Police often felt that there was more to a story other than bias. An officer said,

"We see blacks and whites hanging out all the time. Mostly, everybody gets along, for the most part. Usually something that happens between a black and white, it ain't because they're black and white."

Even response/retaliation incidents, which Nolan (2004) believes can be classified as bias-motivated, are ruled out as hate crimes by police. The focus group debated fictitious scenarios involving two individuals - one black and one white - fighting over a parking spot or engaging in a physical altercation stemming from a traffic accident. The root of these fights is firmly planted in the event itself - the parking spot, the traffic accident. While racial slurs and bias attitudes may emerge, police don't see those as driving elements in the fight. The following remarks also illustrate ambiguity and confusion in identifying bias as a factor.

"Even in the heat of the moment, we go back to two people fighting over a parking space, you know? Probably happens every day. If you go there and one of them has the rebel flag in the 
back of his truck and he is throwing out racial slurs, you know, maybe that wasn't his intent when he left. But now he's, you know. But maybe he's been waiting all day for this or something, you know? It got started in the heat of the moment, but it could turn into one. You've got to see what the circumstances are."

Referring back to the case involving a white mother assaulting her white daughter because she reportedly disapproved of her relationship with a black man, police viewed that as an ordinary domestic call. Even if the mother held bias feelings toward blacks, it is secondary in nature to the crime - assault and destruction of property. Now if the mother targeted the black boyfriend and hung a noose around a tree or burned a cross on his front lawn, police would likely classify that as a hate crime. That type of action is extraordinary and stands alone on its own a hate crime exemplified by extreme behavior. For police to classify an incident as a hate crime, it must stand out solely as a hate crime.

Several of these attitudes reflect organizational behaviors. The approaches and responses to certain situations are learned on the job through personal experiences and organizational protocol. Because hate crimes rarely occur in the eyes of Mountainville police, officers there are not concerned with those types of crimes. A daily routine dominates the reality of a police officer. They often have their hands full with a wide range of crimes from burglary, breakingand-entering, sexual assault, domestic calls, drug-related crimes, forgery, child abuse, and theft, to name a few. Throughout the interview, drugs surfaced as a reemerging topic among officers. At times, police seemed to veer off the topic of hate crimes onto other crimes they handle more frequently. These other crimes reflect the real-world routine of police officers. They are concerned more about these crimes while hate crimes take a backseat. As one officer put it, 
"As long as the drugs and money are squared away, everybody's good. No problem. As soon as somebody does somebody wrong on the drugs or if somebody's messing with somebody's old lady, that's when the shootings start."

The lack of attention to hate crimes may be ingrained in the organizational culture. The lieutenant stated it had been 15 years since the department conducted any sort of hate crime training. Officers present agreed that hate crime training wasn't necessary.

According to one police officer:

"Even a brand new officer would notice, as well as a 30-year officer, if it's a hate crime. My five-year-old daughter would know if it's a hate crime."

Overall, the officers' concept of hate crime appears limited to the extraordinary properties presented in this research. Those properties fit the landmark narratives discussed. To police, if an incident doesn't contain the qualities of a landmark narrative hate crime, it is not a hate crime. All possible hate crimes are measured against extreme cases for a match. Ironically, the three landmark narratives (James Byrd, Matthew Shepard and Megan Williams) serve as archetypical hate crimes though they were not classified as ones in the legal system. Still, police view these instances as undisputed hate crimes, due to the landmark narrative effect. If an event contains extraordinary elements, officers are more likely to classify it as a hate crime because it flies above the radar and does not get lost in the shuffle of an officer's daily routine. The culmination of the factors outlined in this chapter contributes to how police see and don't see hate crimes. As one officer referred to the Megan Williams landmark case, he summed up that everyone would recognize a hate crime if one would occur: 
“Very rarely does someone go out and just whoop somebody's ass because they're gay, black or white. That just don't happen (here). When it does, everyone knows it. I mean, like down in Logan (W.Va.) where the black girl got tied up. Everybody knows it. It's all over the world." 


\section{REFERENCES}

Aaron, Bob. 2009. "Megan Williams Defendant Says Williams Was Tortured.” WCHS-TV. October 23.

Altheide, David. 2003. "The Mass Media as a Social Institution." Handbook of Symbolic Interaction (pp. 657-84). Walnut Creek, CA: Alta Mira Press.

Anti-Defamation League. 2008. Anti-Defamation League State Hate Crime Statutory Provisions. Retrieved November 10, 2010 (http://www.adl.org/99hatecrime/state_hate_crime_laws.pdf).

Bell, Jeannine. 2002. Policing Hatred: Law Enforcement, Civil Rights, and Hate Crime. New York: New York University Press.

Bennett, Susie, James J. Nolan and Norman Conti. 2009. "Defining and Measuring Hate Crime: A Potpourri of Issues." Hate Crimes Volume 1: Understanding and Defining Hate Crime. 16382.

Best, Joel. 1990. Threatened Children: Rhetoric and Concern about Child-Victims. University of Chicago Press.

Best, Joel. 1999. Random Violence: How We Talk About New Crimes and New Victim. Berkeley and Los Angeles: University of California Press.

Best, Joel. 2001. Damned Lies and Statistics: Untangling Numbers from the Media, Politicians and Activists. Berkeley and Los Angeles: University of California Press.

Breen, Tom, and Matt Leingang. 2009. "Megan Williams of West Virginia Recants Allegations in Torture Case." Associated Press. October 21.

Charleston Daily Mail staff reports. 2007. "FBI enters case of ghastly abuse; Logan County mobile home becomes torture chamber for Charleston woman."

Charleston Daily Mail staff reports. 2008. "Suspect in torture case pleads guilty."

CNN. 1997. “Turner Diaries Introduced in McVeigh Trial.” Retrieved December 12, 2010 (http://articles.cnn.com/1997-04-28/us/9704_28_okc_1_timothy-mcveigh-mcveigh-trialoklahoma-state-trooper?_s=PM:US)

Corbin, Juliet, and Anselm Strauss. 1990. "Grounded Theory Research: Procedures, Canons, and Evaluative Criteria.” Qualitative Sociology 13(1):3-20.

Cronin, Shea, Jack McDevitt, Amy Farrell and James J. Nolan. 2007. "Bias-Crime Reporting: Organizational Responses to Ambiguity, Uncertainty, and Infrequency in Eight Police Departments." The American Behavioral Scientist 51(2):213-225, 227-231. 
DeBoskey, Bruce H. 2009. "Wyoming Should Have Its Own Hate Crime Law.” Casper StarTribune.

Federal Bureau of Investigation. 1997. Hate Crime Data Collection Guidelines. Washington, D.C: U.S. Government Printing Office.

Federal Bureau of Investigation. 2011. Hate Crimes. Retrieved January 15, 2011

(http://www.fbi.gov/about-us/investigate/civilrights/hate_crimes).

Garfinkel, Harold. 1967. Studies in Ethnomethodology. Englewood Cliffs, N.J.: Prentice Hall, Inc.

Goodwin, Charles. 1994. "Professional Vision.” American Anthropologist. 9693):606-633.

Grattet, Ryken and Valerie Jenness. 2005. "The Reconstitution of Law in Local Settings: Agency Discretion, Ambiguity, and a Surplus of Law in the Policing of Hate Crime." Law and Society Review 39(4):893.

Harki, Gary. 2007. "No Hate Crimes Charges in Torture Case." Charleston Gazette, September 13, pp. A1.

Harki, Gary. 2008. "She Wasn't There Hating by Herself; Black Leaders React to Indictments in Williams Case." Charleston Gazette. February 7, pp. A1.

Harki, Gary. 2009. "Williams Abuse Case Torture Victim's Story Changes Again.” Charleston Gazette. November 7, pp. A1.

Jenness, Valerie. 1999. "Managing Differences and Making Legislation: Social Movements and the Racialization, Sexualization and Gendering of Federal Hate Crime Law in the U.S." Social Problems 46(4):548-571.

Jenness, Valerie, and Ryken Grattet. 2001. Making Hate A Crime: From Social Movement to Law Enforcement. New York: Russell Sage Foundation.

Jenkins, Philip. 1994. Using Murder: The Social Construction of Serial Homicide. New York: Walter de Gruyter, Inc.

Johnson, John M. 2008. "Horror Stories and the Construction of Child Abuse." Social Problems: Readings. W.W. Norton.

Kitsuse, John and Aaron Cicourel. 1963. "A Note on the Uses of Official Statistics.” Social Problems 11(2):131-139.

Klinenberg, Eric. 2002. Heat Wave: A Social Autopsy of Disaster in Chicago. Chicago: University of Chicago Press. 
Levin, Brian. 1999. "Hate Crimes: Worse by Definition." Journal of Contemporary Criminal Justice 15(1):6-21.

Levin, Jack and Jack McDevitt. 2003. Hate Crimes Revisited: America's War on Those Who Are Different. Cambridge, MA: Westview Press.

McDevitt, Jack, Jennifer M. Balboni, Susan Bennett, Joan Weiss, Stan Orchowsky, and Lisa Walbolt. 2000. Improving the Quality and Accuracy of Bias Crime Statistics Nationally: An Assessment of the First Ten Years of Bias Crime Data Collection. Washington, DC: U.S. Department of Justice, Bureau of Justice Statistics.

McDevitt, Jack, Shea Cronin, Jennifer Balboni, Amy Farrell, James Nolan and Joan Weiss. 2003. Bridging the Information Disconnect in National Bias Crime Reporting. Washington, D.C: U.S. Department of Justice. Bureau of Justice Statistics.

Merton, Robert K. 1957. Social Theory and Social Structure, revised, Glencoe: The Free Press.

Mohajer, Shaya Tayefe. 2007. "Logan Residents Steered Clear of People Accused in Torture Case." Charleston Daily Mail. September 13, pp. A2.

Mohajer, Shaya Tayefe. 2008. "Woman Pleads Guilty to Hate Crime in Torture Case." Charleston Daily Mail. February 8, pp. C3.

Nichols, Lawrence T. 1997. "Social Problems as Landmark Narratives: Bank of Boston, Mass Media and 'Money Laundering." Social Problems 44(3):324-41.

Nichols, Lawrence T., James J. Nolan and Corey J. Colyer. 2008. "Scorekeeping Versus Storytelling: Representational Practices in the Construction of Hate Crime." Studies in Symbolic Interaction 30:361-79.

Nolan, James J., and Yoshio Akiyama. 1999. "An Analysis of Factors That Affect Law Enforcement Participation in Hate Crime Reporting." Journal of Contemporary Criminal Justice 15(1):111-27.

Nolan, James J., Jack McDevitt, Shea Cronin and Amy Farrell. 2004. "Learning to See Hate Crimes: A Framework for Understanding and Clarifying Ambiguities in Bias Crime Classification." Criminal Justice Studies 17(1):99-105.

Nolan, James J., Stephen M. Haas, Erica Turley and Jake Stump. 2011. "Assessing the Validity of Hate Crime Reporting: An Analysis of NIBRS Data." Charleston, WV: Criminal Justice Statistical Analysis Center, Division of Justice and Community Services, Department of Military Affairs and Public Safety.

Pauley, Matthew. 1999. "Murder by Premeditation." American Criminal Law Review 36(2):14570. 
Phillips, Scott and Ryken Grattet. 2000. "Judicial Rhetoric, Meaning-Making, and the Institutionalization of Hate Crime Law." Law and Society Review 34(3):567

Temple-Rastin, Dina. 2002. A Death in Texas: A Story of Race, Murder, and a Small Town's Struggle for Redemption. New York: Henry Holt and Company.

Timmermans, Stefan. 2006. Postmortem: How Medical Examiners Explain Suspicious Deaths. Chicago: University of Chicago Press.

Turpin-Petrosino, Carolyn. 2009. "Black Victimization: Perceptions and Realities." Hate Crimes Volume 3: The Victims of Hate Crimes. 19-44.

U.S. Census Bureau. 2000. American FactFinder. Retrieved January 6, 2011 (http://factfinder.census.gov/home/saff/main.html?_lang=en).

U.S. Department of Justice. 2009. 2008 Hate Crime Statistics. Retrieved October 2, 2010 (http://www2.fbi.gov/ucr/hc2008/incidents.html).

Wise, Kris. 2007. "Unwanted Light Shines on W.Va; Shocking Events in Logan County Attract National Attention." Charleston Daily Mail. September 13, pp. A1.

Zash, Chelsi. 2009. "Man Convicted for 'Ethnic Animosity' in Greensboro Court.” WFMY News 2. Februrary 23.

Zerubavel, Eviatar. 1996. "Lumping and Splitting: Notes on Social Classification." Sociological Forum 11(3):421-33. 